
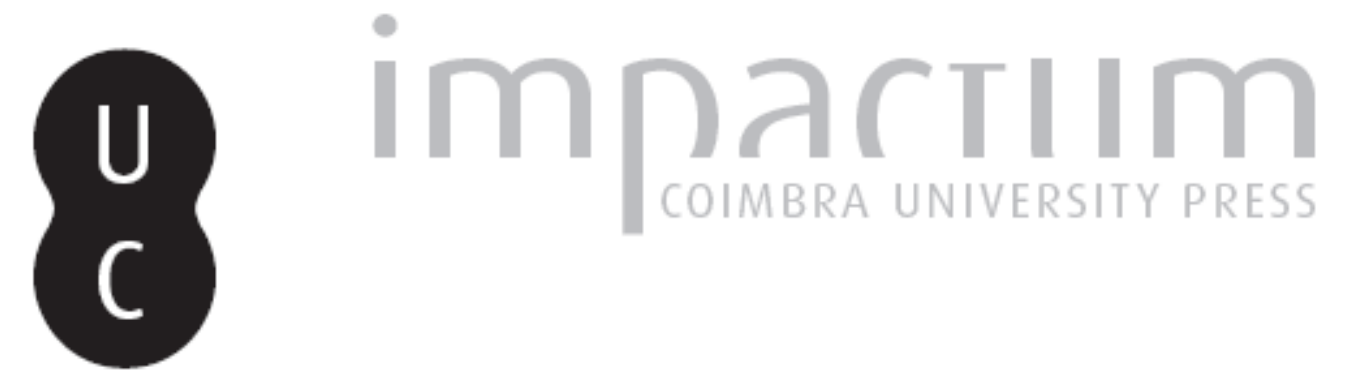

\title{
Do «lluminismo» ao Positivismo: Joaquim António da Silva Cordeiro e a sua obra
}

Autor(es): Homem, Amadeu Carvalho

Publicado por: Imprensa da Universidade de Coimbra

URL persistente:

URI:http://hdl.handle.net/10316.2/43926

DOI:

DOI:https://doi.org/10.14195/2183-8925_3_2

Accessed : $\quad$ 26-Apr-2023 10:45:28

A navegação consulta e descarregamento dos títulos inseridos nas Bibliotecas Digitais UC Digitalis, UC Pombalina e UC Impactum, pressupõem a aceitação plena e sem reservas dos Termos e Condições de Uso destas Bibliotecas Digitais, disponíveis em https://digitalis.uc.pt/pt-pt/termos.

Conforme exposto nos referidos Termos e Condições de Uso, o descarregamento de títulos de acesso restrito requer uma licença válida de autorização devendo o utilizador aceder ao(s) documento(s) a partir de um endereço de IP da instituição detentora da supramencionada licença.

Ao utilizador é apenas permitido o descarregamento para uso pessoal, pelo que o emprego do(s) título(s) descarregado(s) para outro fim, designadamente comercial, carece de autorização do respetivo autor ou editor da obra.

Na medida em que todas as obras da UC Digitalis se encontram protegidas pelo Código do Direito de Autor e Direitos Conexos e demais legislação aplicável, toda a cópia, parcial ou total, deste documento, nos casos em que é legalmente admitida, deverá conter ou fazer-se acompanhar por este aviso.

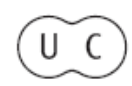




\section{REVISTA DE HISTORIA DAS IDEIAS}

Volume III

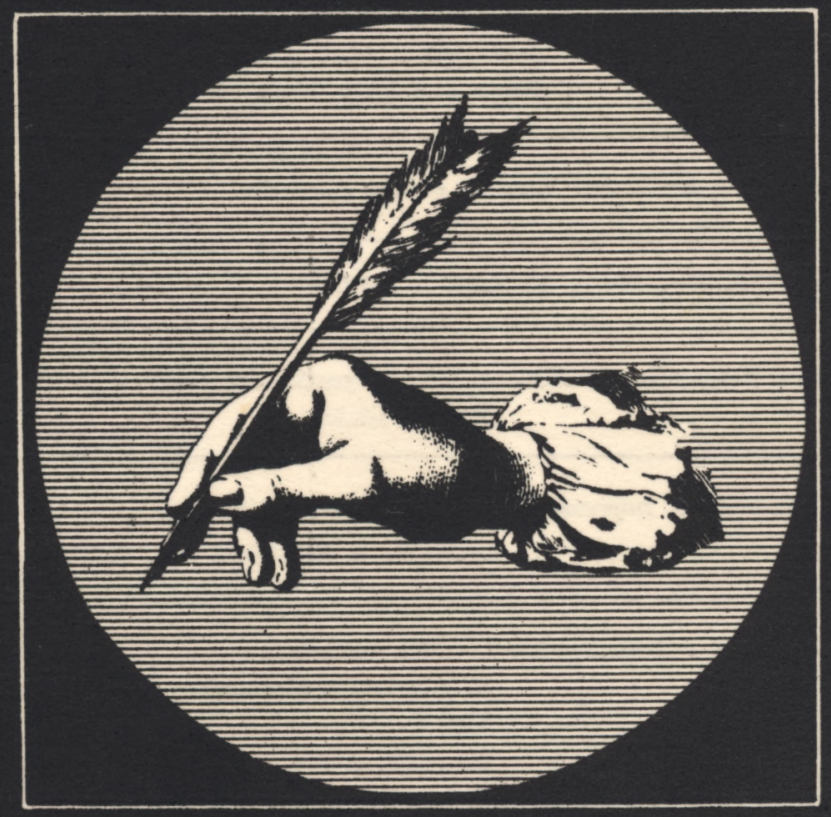

INSTITUTO DE HISTÓRIA E TEORIA DAS IDEIAS

$$
\begin{gathered}
\text { FACULDADE DE LETRAS } \\
\text { COIMBRA } 1981
\end{gathered}
$$




\title{
DO «ILUMINISMO»AO POSITIVISMO
}

\author{
JOAQUIM ANTÓNIO DA SILVA CORDEIRO E A SUA OBRA
}

O propósito inicial que presidiu à elaboração do trabalho que agora publicamos restringia-se ao estudo da obra filosófica e política de Joaquim António da Silva Cordeiro. Fomos alertados para o tema pela avisada sugestão do Professor José Sebastião da Silva Dias, fundador do Instituto de História e Teoria das Ideias da Faculdade de Letras da Universidade de Coimbra e, nessa altura, seu presidente*.

Para viabilizar o programa inicial, tivemos de sistematizar leituras anteriores e de disciplinar reflexões, até então esparsas, sobre a evolução da filosofia em Portugal. Com efeito, remontando a produção teórica de Silva Cordeiro aos finais do período oitocentista, vimo-nos confrontados com a necessidade de abrir um breve inquérito histórico ao estado dos estudos filosóficos nas nossas instituiçס̃es oficiais de cultura, maxime na Universidade portuguesa, para que mais nitidamente pudesse avultar a especificidade do pensamento do autor a tratar. Fácil nos foi concluir que as perspectivas inovadoras entre nós introduzidas no decurso das décadas de 60 e 70 se constituíram à margem dos conteúdos da cultura oficial e até contra os seus mais qualificados corifeus. Com efeito, os sinais de progresso mental que surgem no nosso país a partir dos meados do século, derivam muito mais da curiosidade um tanto anárquica duma geração de férteis «vencidos» do que do labor disciplinado da pedagogia universitária. Porquê isto? Fundamentalmente porque a Universidade portuguesa permaneceu directamente vinculada aos modelos filosóficos traçados pela reforma pombalina

* Queremos deixar aqui expresso o nosso agradecimento ao ilustre Mestre. Sem o calor do seu incentivo, a franqueza da sua disponibilidade e a justeza do seu conselho este estudo ficaria, muito provavelmente, no limbo das «boas intenções» permanentemente adiadas. 
de 1772, designadamente às Instituições de Genovese e às Positiones de Martini, sem já falar na proeminência entre nós alcançada e longamente mantida pelas Éticas de Job e Heinécio. O «iluminismo» pombalino, no plano do pensamento filosófico, conheceu o destino que a regulação interna do processo histórico sempre reserva a toda a mundividência teórica que teima em perdurar para lá dos convenientes limites da sua eficácia temporal; nascido da estrénua luta antiperipatética, haveria de converter-se, ele próprio, numa nova e requentada Escolástica.

Deste acervo de reflexð̃es, talvez demasiado óbvias, nasceu o primeiro capítulo do nosso trabalho.

Estudámos, no segundo capítulo, a personalidade filosófica e política de Joaquim António da Silva Cordeiro. A sua primitiva sujeição aos moldes do pensar positivista não nos surpreendeu. Como homem do seu presente, compartilhava da crença comum na regeneração política e social do seu povo, mediante a conversão colectiva à matriz sociológica dum Comte e dum Littré. Neste padrão de pensamento se firmou a conviç̧ão republicana que triunfaria em 1910. Mas Silva Cordeiro não se manteria por muito tempo fiel às lucubrações da sua juventude. As antigas verdades, hauridas no autor do Curso de Filosofia Positiva, cedo se convertem em decepções. E vemo-lo, em plena maré alta do ataque republicano, assinar uma obra de vanguarda - A crise em seus aspectos morais (1896) - que desacredita por igual tanto o decrépito constitucionalismo monárquico como o abstracto e místico republicanismo positivista. Lassalle, Proudhon e Marx são-lhe familiares. O mutualismo operário afigura-se-lhe promissor. Pretende ver resolvida a «questão social» «saindo dos moldes da sociedade actual». Parece ter lobrigado no socialismo a saída mais adequada para as contradiçð̃es de interesses que o tempo ia patenteando com crueza.

Fica assim sumariamente referido o escopo do nosso trabalho. Se outros méritos não tiver, que contribua, ao menos, para salvar dum injusto esquecimento a obra de alguém que soube criticar o seu presente em nome do nosso futuro. 


\section{I - APONTAMENTOS SOBRE A EVOLUÇÃO DA FILOSOFIA EM PORTUGAL: DO ILUMINISMO AO CIENTISMO}

\section{A CRÍtICA ANTI-ESCOLÁSTICA PRÉ-VERNEIANA}

Quando Luís António Verney fez publicar, em 1746-47, o seu Verdadeiro Método de Estudar, logo se verificou terem ficado ainda mais cerceadas as possibilidades de sobrevivência da filosofia peripatética nas nossas instituições culturais. Com efeito, o seu esforço secundava, de forma mais sistemática e demolidora, a corrente crítica que, no dobrar do século anterior, fora iniciada por um círculo de aristocratas amigos das novas «luzes» e das perspectivas de inovação pedagógica reclamadas pelo progresso mental e material do país. São estas exigências de actualização e modernidade que se assinalam no escopo das "Conferências Discretas e Eruditas", promovidas pelo 4. ${ }^{\circ}$ Conde da Ericeira, D. Francisco Xavier de Meneses (1). A reformulação dos conteúdos culturais, desejada pelo círculo ericeirense, iria ser prosseguida, no transcurso das primeiras décadas do século XVIII, por um notável escol de pensadores e cientistas, especialmente atentos ao movimento das ideias da Europa culta.

Não poderá, contudo, avaliar-se o alcance da crítica formulada por estes «estrangeirados» sem que se digam duas palavras sobre o estado de profunda letargia em que se encontravam mergulhados, em Portugal, os estudos filosóficos.

Os nossos programas do ensino superior mantinham-se estreitamente vinculados à «lição de Aristóteles», consagrando-lhe a suprema autoridade na Lógica, Física e Ética. No melhor dos casos, apenas moderavam este avassalador primado, associando à Lógica a inspiração de Porfírio e à Ética o contributo de S. Tomás. Também os critérios didácticos então vigentes desfavoreciam e desencorajavam a insólita criatividade de um ou outro espírito mais independente. Tudo gravitava em torno do texto aristotélico. Além de lido e discutido oral-

(1) Sobre a biografia intelectual de D. Francisco Xavier de Meneses e sobre os conteúdos «iluministas» do círculo ericeirense, vide OfÉlia Milheiro Caldas Paiva Monterro, No alvorecer do «iluminismo» em Portugal - D. Francisco Xavier de Meneses, 4. ${ }^{\circ}$ Conde da Ericeira, Coimbra, 1965. 
mente, era ele objecto do comentário pessoal com que o docente pretendia esconjurar as dificuldades ou obscuridades textuais. As grosas dos comentadores abriam assim a porta a toda a gama de subtilezas disputativas e de casuísmos argumentativos, que mais concorriam para a insanável obscuridade da lição do que para a sua escorreita fidelidade e clareza (1).

É certo que no decurso do século XVII se encetara um louvável esforço de manualização, visando conferir alguma unidade e sistematização ao acumulado labor dos comentaristas. O trabalho dos «Conimbricenses» - Manuel de Góis, Sebastião do Couto, Baltazar Álvares, Cosme de Magalhães- - orienta-se neste sentido. O fundo da metodologia permaneceu, porém, inalterado, continuando a preponderar, no âmbito dum discurso livreseo e pouco original, o culto tautológico das grosas e a sujeição completa à autoridade.do mentor da Escola. E são ainda protestos veementes de fidelidade às velhas Lógica e Dialéctica e à exầngue temática da Filosofia Conimbricense os que vamos encontrar nos últimos representantes desta senda pedagógici tais como Gregório Barreto ou Bento de Macedo (2).

Uma Lógica que se perdia na disputa, uma Física que se exauria na análise formalizante e qualitativa dos seres, uma Metafísica e um? Ética que sacrificavam a sua autonomia nas aras da Revelação racionalizada, eis, numa palavra, as referências filosóficas gativas a que se aplicaram os nossos «iluministas».

$\mathrm{O}$ afrontamento iria operar-se sob o signo dum novo valor: o dum experiencialismo - ou até dum experimentalismo - ericarado como susceptível de rebater as insulsas abstracções da razão formalı A concretização desta nova visão do mundo passará pela assimilação ecléctica das perspectivas substanciais e metodológicas de Descartes, Gassendi, Bacon, Locke e Newton, com profusas referências à legião doṣ seus seguidores (3).

A rotura já se prenunciava na obra do clérigo regular de $\mathrm{S}$. Caetano, Rafael Bluteau, o qual, subordinando ainda basicamente o contorno

(1) Vide comentários de António Salgado Júnior in Luís António Verney, Verdadeiro Método de Estudar, 3. ${ }^{a}$ ed., vol. 3. ${ }^{\circ}$, Lisboa, 1949-52, pp. 4-6.

(2) Vide Lopes Praça, História da Filosofia em Portugal, Lisboa, 1974, pp. 222-24.

(3) Vide Hernâni Cidade, Lições de Cultura e Literatura Portuguesas, 5." ed., vol. 2. ${ }^{\circ}$, Coimbra, 1968, pp. 29-62. 
do seu pensar à referência peripatética, não deixava de expressar alguma independência judicativa nos domínios ético, ontológico e lógico (1). $\mathrm{O}$ teatino, que D. Francisco Xavier de Meneses associara a projectos de desenvolvimento industrial do país, reagia fortemente contra o pendor exageradamente especulativo da teologia escolástica e mostrava-se de algum modo permeável às promessas do experimentalismo. Nas suas Prosas Portuguezas, desabafava desta forma expressiva: «Sei, que nas nossas Universidades .... as primeiras cadeiras delas com o nome de Teologia, são destinadas para conhecer a Deus. Mas nesta sagrada matéria, quantas frívolas questões levanta a subtileza Escolástica? E quantas vezes se mete em labirintos, donde nem com o fio de Ariadne poderá achar saída? Hoje tudo são questões de Possibili, et de impossibili. Chega a curiosidade teológica a querer saber o que Deus fazia antes da criação do Mundo. .... Nos exercícios desta Sagrada Palestra tudo são expressões, e quasi terrmos inacessíveis a uma mediana inteligência; ... e em todos os Tratados Teológicos, ambiguidades, que suspendem o juizo, e matérias escabrosas, com que se podem fomentar contendas até o fim do Mundo» (2).

Foi também o experimentalismo newtoneano e a metodologia baconeana que serviram de guia a um outro sábio lusitano: Jacob de Castro Sarmento. A primeira preferência explicita-se no próprio título de uma sua obra: a Theoria verdadeira das marés, conforme a filosofia do incomparável cavalheiro Isaac Newton. Nela encontramos as mais vivas diatribes contra a filosofia tradicional, lastimando Castro Sarmento que entre nós se continuasse a esbanjar talento com os entes de razão, os universais «e outras fábulas desta casta, de que se compõe e está cheia a Aristotélica (Filosofia), indignas do juízo e da atenção humana» (3). Quanto ao seu pendor para a metodologia baconeana,

(1) Cfr. J. S. da Silva Dias, O eclectismo em Portugal no século XVIII. Génese $e$ destino de uma atitude filosófica, in "Revista Portuguesa de Pedagogia», nova série, Ano VI, Coimbra, 1972, pp. 5-6.

(2) Rafael Bluteau, Prosas Portuguezas, Lisboa, 1728, pp. 341-42.

(3) «Agora te pergunto, leitor sincero, e desapaixonado, não seria melhor para o particular, e para o público, que a agudeza dos nossos grandes génios, se empregasse em uma Filosofia, que mostra aos olhos, o que dita aos ouvidos, e tráz estes, e outros descobrimentos à República; do que fatigar-se, e consumir com uma continuada, inútil controvérsia de Utrum detur Ens Rationis; Universale a parte rei; e outras Fábulas desta casta, de que se compõe, e está cheia a Aristotélica, indignas do juízo, e atenção humana?» (JACOB DE CASTRO SARMENTo, Theuria verdadeira das 
lembremos o conselho por ele dado a $\mathrm{D}$. João $\mathrm{V}$ para que a reforma dos estudos médicos se fizesse em concordância com o espírito de Francis Bacon, de quem também iniciou, por mandato régio, a tradução das obras.

Em Manuel de Azevedo Fortes encontramos a apologia duma lógica «more geometrico», na senda duma inspiração cartesiana facilmente detectável e em contradição com os modelos operativos duma lógica escolástica que, segundo as suas palavras, «mais servia para embaraçar e confundir as nossas ideias do que para aperfeiçoar as operações do entendimento» (1).

E que outra coisa não são os Apontamentos sobre a educação de um menino nobre, de Martinho de Mendonça, senão uma tentativa para introduzir nas práticas pedagógicas nacionais os ideais educativos de John Locke, com todo o seu pendor utilitarista e o seu culto pelo espírito experimental (2)?

\section{O «VERDADEIRO MÉTODO DE ESTUDAR» ANTE A ESCOLÁSTICA}

Foi, contudo, a obra do Barbadinho - precedida, como se referiu, por todo um discurso iluminista de travo anti-escolástico - que sistematizou a esparsa crítica anterior, lançando sobre os glosadores de Aristóteles o mais contundente dos requisitórios (3).

Compulsado o Verdadeiro Método nos capítulos respeitantes aos estudos filosóficos, desde logo se torna visível o significado globalizante da crítica verneiana. Não é este ou aquele enfoque que se questiona,

marés, conforme à philosophia do incomparavel cavalheiro Isaac Newton, Londres, 1737, Prologo ao leytor.)

(1) Manoel de Azevedo Fortes, Logica Racional, Geométrica, e Analitica, Lisboa, 1744, Antiloquio.

(2) Sobre o ideário pedagógico de Martinho de Mendonça, vide JoAQuim Ferreira Gomes, Martinho de Mendonça e a sua obra pedagógica, Coimbra, 1964. Veja-se especialmente o cap. $3^{\circ}$, pp. 131-47, consagrado ao estudo da influência lockeana nos «Apontamentos».

(3) Para um estudo mais integrado e desenvolvido da obra de Verney e das muito amplas repercussões que ela suscitou dentro e fora de Portugal, vide J. S. DA Silva Dias, Portugal e a cultura europeia, in «Biblos», vol. 28. ${ }^{\circ}$, Coimbra, 1952, pp. 386-431. Vide também António Alberto de ANDRADE, Vernei e a cultura do seu tempo, Coimbra, 1965 e Verney e a projeção da sua obra, Amadora, 1980. 
esta ou aquela casuística de que se dissente, esta ou aquela problemática que se interpela. Pelo contrário, o autor aplica-se a comprovar a inanidade de toda a Lógica (Carta Oitava), a vacuidade de toda a Metafísica (Carta Nona), a insuficiência de toda a Física (Carta Décima), a fatuidade de toda a Ética (Carta Undécima), tal como eram professadas pelos serôdios discípulos do filósofo de Estagira. E o cerne gnoseológico de tal demolição dimana directamente do Ensaio sobre $o$ entendimento humano, de Locke. O fundo sensista da obra de Verney deriva, com efeito, duma subordinação quase literal aos critérios do empirista inglês (1). Dele aceita a distinção entre ideias simples ou adventícias e ideias compostas ou factícias, defendendo que as primeiras se imprimem na mente através de experiências sensitivas originárias e que as segundas resultam da complexão que o poder relacional do espírito é capaz de activar, partindo dessas primeiras experiências (2). Assim, a capacidade discursiva e o rigor do juízo e do raciocínio procedem da correcta ordenação e conexão dessas ideias, não carecendo o espírito humano duma aparatosa «máquina de regras» silogístico-formais para discorrer com justeza (3). Ele liberta-se dos enganos e ciladas através duma eficaz disposição natural que lhe permite a homologação dos actos de conhecimento $\left({ }^{4}\right)$. A velha silogística escolástica, mantendo uma vestigiária utilidade como método de exposição adverso à prolixidade e ao rodeio da grande tirada oratória, patenteia uma notória esterilidade como método de descoberta. É que «o silogismo não faz mais que mostrar a conexão das partes, sem ensinar a buscar as provas» $(5)$, ou, dito doutra maneira, «a silogística somente

(1) Tal filiação encontra-se definitivamente demonstrada por ANTónio SALGADO JÚNIOR. Leiam-se os seus comentários à Carta Oitava do Verdadeiro Método, na edição atrás mencionada.

(2) «Um menino.... não tem outros conhecimentos senão os que entram pelos sentidos. Os que defendem ideias inatas, que mostrem alguma que não entre pelos sentidos, ou não se deduza das ideias que entraram por eles. Estou certo que não aparecerá alguma a que não possamos descobrir esta origem. São, pois, os sentidos as principais portas pelas quais entram as ideias na alma" (Verdadeiro Método de Estudar, III, pp. 82-83). As posteriores citações desta obra passarão a fazer-se através das iniciais V.M.E.

(3) V.M.E., III, p. 52.

(4) «A nossa mente tem, de sua natureza, a facilidade de conhecer a conexão destas ideias e pô-las em boa ordem, e tirar delas conclusões justas, sem que para isso a preparem com artifício algum» (V.M.E., III, p. 59).

(5) V.M.E., III, p. 56. 
ensina a inferir, não a conhecer as premissas: se uma delas for falsa, será falsa a conclusão» (1).

Fiel ao horizonte iluminista, o autor do Verdadeiro Método pretende ver excluído do campo científico o culto da autoridade. Apela, assim, para os direitos da razão crítica individual, ridicularizando os que «como carneiros ...., antes querem errar por cabeça alheia, que acertar pela própria» (2). Verney assume aqui a evidência cartesiana como critério de certeza, sem deixar, porém, de se inserir na linha dos que valorizam mais o que se prova do que o que se diz (3). A enumeração das causas do erro e das "ocasiões de engano» parece filiar-se na teoria baconeana dos «idola».

Passando da Lógica à Metafísica, Verney centra toda a sua crítica na contestação da autonomia de tal disciplina. Os escolásticos compraziam-se em distinguir a Metafísica Intencional da Metafísica Real. Para eles, a primeira ocupar-se-ia das distinções e divisð̃es ontológicas, enquanto que a segunda estudaria as realidades «pneumatológicas» divinas, angélicas e anímicas. $O$ Barbadinho nega a validade da distinção e dissolve na Lógica a Metafísica Intencional e na Física a Metafísica Real (4). Para ele, a Metafísica só ressalvará a sua utilidade se puder confinar-se «a definir com clareza alguns nomes de que se servem os Filósofos, e a entender e perceber bem alguns axiomas, ou proposições claras, que pertencem aos ditos» (5). Também aqui se pressente a tributação do Ensaio de John Locke, o qual confina a amplitude gnoseológica à Lógica, Física e Ética e exclui do seu âmbito a Metafísica.

(1) V.M.E., III, p. 62.

(2) «.... o método de filosofar não se deve seguir porque o diz este ou aquele autor, mas porque a razão e a experiência mostram que se deve abraçar. Isto é o que eu não posso meter em cabeça a muita gente, porque a maior parte do mundo não examina os princípios das coisas, mas vão uns detrás dos outros, como carneiros, sem mais eleição que o costume, e antes querem errar por cabeça alheia, que acertar pela própria» (V.M.E., III, p. 75).

(3) «.... não admito senão aquilo que me provam com clareza e verdade» (V.M.E., III, p. 77). «Consiste o critério da verdade na evidência com que se propõe uma coisa, de sorte que não deixe duvidar de ser assim» (Idem, p. 100).

(4) «.... é loucura separar estas metafísicas das outras partes da Filosofia. Metafísica Intencional é pura Lógica; Metafísica Real é pura Física; e tudo o mais são puerilidades» (V.M.E., III, pp. 120-121).

(5) V.M.E., III, p. 155. 
A modernidade do nosso filósofo alcança suprema altura no tratamento da Física. O que aí se preconiza é uma verdadeira revolução de métodos, através da substituição de conjecturas e hipóteses improvadas e improváveis, nascidas da emaranhada exegese a que a teoria hilemórfica dera lugar, por um novo espírito em que se acasalam o rigor da observação e o princípio da evidência matemática ${ }^{(1)}$. A Escola Peripatética construíra uma Natureza ideal e apriorística. Por isso, segundo Luís António Verney, urgia empreender a tarefa de explicar os efeitos naturais pela descoberta das suas verdadeiras causas, libertando-os para sempre dum quadro fixo de referências puramente formais. Um tal apriorismo opunha-se à percepção do modo específico de revelação dos princípios em que assentava o mundo físico. Tal revelação, por não ser imediata, não se compadecia com súbitas iluminações do espírito. A tal se opunha, desde logo, o cariz duma ciência «que examina a natureza do Corpo .... mediante os efeitos que conhecemos» (2) e que «alcança o conhecimento da natureza de todas as coisas por meio das suas propriedades e da redução aos próprios princípios» (3). Daqui resultava que o conhecimento da esfera física era um conhecimento mediato e que os instrumentos mediadores da respectiva disciplina científica eram a observação, por um lado, e a razão experimental, por outro (4).

Apesar disto, não é sobre Aristóteles - ou, pelo menos, sobre toda a sua obra - que Verney lança o vigor dos seus anátemas. O espírito de observação cultivado nos tratados De Animalibus do Estagirita mostrara «o uso que se deve fazer da experiência, e o modo com que se deve tratar a Física» (5). Mas os seus discípulos, ao prescindirem radicalmente da via experiencial e ao subordinarem-se sem remédio

(1) «Para discorrer bem sobre a natureza é necessário ter juizo claro, com todos os requisitos para observar bem: observar muito e bem, ou saber-se servir dos que o fizeram, e fundar os seus raciocínios em princípios evidentes, quais são os matemáticos» (V.M.E., III, pp. 182-83).

(2) V.M.E., III, p. 207.

(3) V.M.E., III, p. 168.

(4) «Nós não temos conhecimento imediato das naturezas; unicamente temos dois meios para o conseguir: observar as propriedades e ver se, mediante alguma resolução, podemos chegar a conhecer os princípios de que se compõe esta ou aquela entidade física. Este deve ser o primeiro emprego do Físico: observar e discorrer» (V.M.E., III, p. 190).

(5) V.M.E., III, p. 174. 
à subtileza das suas «altíssimas contemplações, cobertas com o véu de palavras pouco comuns e fora do significado usual» (1), tinham instaurado um insanável divórcio entre a Escola e o novo espírito. Proclama, por isso, o autor do Verdadeiro Método: "Quem recebe as experiências, e, em virtude delas, quer discorrer, deve renunciar ao Peripato; quem abraça o Peripato deve renunciar às experiências. São coisas totalmente opostas, que uma destrói a outra» (2).

Verney recomenda ainda que se estabeleça uma aliança muito íntima entre a Física e a Matemática, pois só assim se poderão compreender os princípios de extensão e movimento dos corpos (3). Desta maneira, considerava que a resistência dos escolásticos à introdução do raciocínio matemático no campo da Física não deixava de traduzir um gı osseiro preconceito e uma cerrada ignorância.

Em resumo: à dominância da inspiração lockeana nos domínios lógico e metafísico irá corresponder, no conspecto da Física, uma vincada preferência pelas directrizes newtoneanas, conjugada com numerosas referências aos mais relevantes cultores do pensamento físico-matemático: Descartes, Pascal, Mersenne, Torricelli, Huyghens, Cheyne, etc. (4).

Terminaremos este ponto com duas palavras acerca da reflexão verneiana sobre a Ética, que, novamente em contradição com a escolástica tradicional, não é vista como un subalterno apêndice da Teologia. Ela deverá antes ser considerada como uma propedêutica indispensável ao desenvolvimento do saber teológico, «porque lhe prepara a estrada, confirmando as suas conclusões con a autoridade dos Filósofos e com os princípios da boa razão» (5). Esta prioridade metodológica do emprego da recta razão, embora sem pôr em causa a posterior adesão aos critérios morais dos conteúdos revelados, não deixa de configurar uma orientação divergente da dos mestres da Escola.

Verney pisa com muita prudência os terrenos resvaladiços da Ética. Não se detectam especiais prevenções contra o jusnaturalismo dum Grócio, dum Pufendorf ou dum Heinécio. Porém, ante doutri-

(1) V.M.E., III, p. 198.

(2) V.M.E., III, pp. 183-84.

(3) «De sorte que, entre os homens doutos, querer ser Físico sem Matemática é heresia» (V.M.E., III, p. 217).

(4) Cfr. V.M.E., III, pp. 216-23.

(5) V.M.E., III, p. 263. 
nações mais perigosas ou controversas - como as de Espinosa, Hobbes ou Locke -, o Barbadinho assumirá uma atitude de prudente reserva. Dirá que eles são "autores que têm muita coisa boa e também muita má» e que, por isso, «não servem senão para homens feitos e bem fundados nos princípios da Religião Católica, que os podem ler sem perigo e deles tirar o que é útil» (1). Mas o leitor facilmente reconhece, sob a capa desta cauta circunspecção, o evidente intento de fazer estalar a casca duma casuística ético-teológica, repassada por «metafísicas sumamente desnecessárias» (2).

\section{OS ORATORIANOS}

Os Padres de S. Filipe de Néri reagiram com um modernismo mitigado aos conteúdos da Peripatética lusitana. O estudo da sua aç̧ão pedagógica não pode ser descurado, visto que, sobretudo a partir do segundo quartel do século XVIII, os Oratorianos disputaram vitoriosamente aos Jesuítas o monopólio do ensino público e nele deram mostras de acertada moderação. Moderação que correspondeu, de resto, a uma visceral opção gnoseológica dos Néris: a que articula a crença no poder da racionalidade, quando aplicada ao domínio do sensível, com o reconhecimento da sua limitação, na esfera do trans-sensível (3). Assim se afirma um eclectismo de coloração muito particular, na sua fidelidade metafísica à lição dum Estagirita que se desejava ver urestituído» à sua pureza originária, mas também na sua pronta abertura ao naturalismo da filosofia moderna.

Assim, na Philosophia Aristotelica Restituta et Illustrata qua experimentis, qua ratiociniis nuper inventis, o P. e João Baptista atribui-se o empenho de "adornar a antiga Filosofia de Aristóteles com novos raciocínios e experiências», advertindo, porém, que tal observância não era tão religiosa que dela se não pudesse desviar um pouco, «numa ou noutra questão, não atinente à medula do sistema» ( $\left.{ }^{4}\right)$. A posição

(1) V.M.E., III, p. 298.

(2) V.M.E., III, p. 254.

(3) Cfr. J. S. DA Silva Dias, ob. cit., p. 20.

(4) JoÃo Baptista, Philosophia Aristotelica Restituta..., apud Lopes PraÇA, ob. cit., p. 230. 
de João Baptista, embora apartada das corruptelas da Escolástica mais tardia, não dissente no fundamental da Lógica e da Metafísica aristotélicas. A verdadeira revolução vai operar-se no domínio da Física, por onde irrompem, sem quaisquer ambiguidades, as experiências de Galileu, Torricelli, Tosca, Maignan e, muito em especial, as de Descartes, Gassendi e Newton (1).

Tem também significado o facto dos lógicos Oratorianos - como João Barbosa, António Soares, Rodrigo de Matos, Manuel Álvares e Teodoro de Almeida - se terem distanciado dos sofismas disputativos e das formalizações silogísticas, optando por esquemas mais compagináveis com a lógica lockeana e com a metodologia newtoneana, que perfilhavam (2). Manuel Álvares foi, aliás, um acérrimo defensor da escola nova. As referências aos filósofos mais heterodoxos eram acompanhadas, nas suas obras, de tão encomiásticas adjectivações que a Inquisição o aconselhou a suprimir tal apologética (3). Mesmo assim, Verney é por ele qualificado de «eruditíssimo»; o sistema copernicano devia ser admitido, «ao menos como hipótese» (4); a lógica dos antigos aparece-nos apodada de quimérica, por se ocupar dos «entes de razão, primeiras e segundas intençð̃es» e de "outras coisas perturbadoras da mente» (5).

Diremos ainda que nem a profundíssima vivência cristã de Teodoro de Almeida, autor da celebrada Recreação Filosófica, enjeita o recurso a Descartes e a Wolff para contestar, a partir deles, a impiedade dos sequazes de Voltaire, Rousseau e Helvetius (6).

(1) Reportando-se a este aspecto, o Professor Silva Dias sublinha que foi "com ele, e não com o Barbadinho .... que a filosofia tradicional morreu efectivamente, entre nós, no plano da física» (Ob. cit., p. 12).

(2) Cfr. J. S. da Silva Dias, ob. cit., pp. 8-10.

(3) Cfr. Hernâni Cidade, ob. cit., vol. 2.0, p. 167.

(4) Manuel Álvares, Historia da creação do Mundo, conforme as ideias de Moisés e dos Filósofos..., apud Hernâni CidAde, ob. cit., vol. 2. ${ }^{\circ}$, pp. 164 e 169.

(5) Idem, Instrução sobre a lógica ou diálogo sobre a filosofia racional, apüd Hernâni Cidade, ob. cit., vol. 2..$^{\circ}$ p. 167.

(6) Cfr. J. S. DA Silva Dias, ob. cit., pp. 17-18. 


\section{RADICAÇÃo Do ECLECTISMO SENSISTA}

À derrota teórica da Escolástica irá corresponder, no plano institucional, a reforma pombalina dos estudos universitários (1772), precedida, aliás, pela expulsão dos discípulos de St. ${ }^{\circ}$ Inácio (1759).

A obra pedagógica do ministro de D. José não alvejava apenas os glosadores e comentadores do Perípato português. Pretendia, para além disto, eliminar radicalmente a proeminência de Aristóteles dos currículos escolares nacionais ( ${ }^{1}$ ). Os Estatutos Universitários de 1772, em correspondência plena com os propósitos do poderoso marquês, propõem-se extirpar do ensino coimbrão os conteúdos e métodos do saber escolástico e fomentar, dentro dos limites consentidos pela teoria do poder defendida por Pombal, uma certa postura de independência crítica, requerida pelo experimentalismo e pela estimulação das práticas de observação activa da natureza (2). Lançam-se, deste modo, os alicerces dum eclectismo de raiz sensista, mais voltado para preocupaçð̃es importadas do horizonte científico moderno do que para grandes vôos metafísicos.

(1) Deverá notar-se que, dum modo geral, os nossos críticos antiperipatéticos visavam mais os excessos da Escola do que a filosofia do seu mentor. O próprio Verney alveja com a sua verrina não tanto a filosofia aristotélica, mas muito mais os desvios dos posteriores comentaristas «arabizantes». Ao contrário, Sebastião José de Carvalho e Melo visa o próprio Aristóteles. É peremptório o testemunho que se colhe da carta dirigida por Pombal ao Reitor Reformador, D. Francisco de Lemos, em 23 de Fevereiro de 1773: «O Estatuto da Universidade impugnou Aristóteles, e sempre o nome de um filósofo tão abominável se deve procurar que antes esqueça nas lições de Coimbra, do que se apresente aos olhos dos académicos como um atendivel corifeu da filosofia». (Apud J. S. DA Silva Dias, ob. cit., pp. 16-17).

(2) Segundo os Estatutos da Universidade de Coimbra de 1772, urgia «abolir e desterrar a Filosofia Escolástica, entendendo-se por Escolástica toda aquela que se compuser de questões quodlibéticas, metafísicas, abstractas e inúteis, que como sofismas intermináveis se disputam pela afirmativa e pela negativa, semelhantes às que escreveram os comentadores de Aristóteles em qualquer das seitas em que se dividiram» (Estatutos da Universidade de Coimbra de 1772, liv. 3. ${ }^{\circ}$, Coimbra, 1972, Introdução, pp. 2-3). Consignavam ainda os mesmos Estatutos: «E procurará (o professor) que os discípulos não sejam meros espectadores; mas trabalhem e façam por si as mesmas experiências; para se formarem o gosto de observar a natureza; e de contribuírem por si mesmos ao adiantamento e progresso da Ciência, a qual não se enriquece com sistemas vãos, e especulações ociosas, mas com descobrimentos reais, que não se acham de outro modo, senão observando, experimentando e trabalhando". 
A vanguarda dos pensadores portugueses conhecia bem, como se viu, o empirismo de Locke. Mais tarde, em Abril de 1794, pela pena de José Freire de Carvalho, traduzir-se-ia a Arte de pensar, de Condillac (1). Foi esta corrente empírico-sensista que, caldeada pelo remanescente do espiritualismo escolástico e pelo racionalismo leibniziano e wolffiano, se veio a impôr entre nós.

Nos inícios de 1773, Pombal fez adoptar como compêndio da cadeira de Filosofia Racional e Moral da recém criada Faculdade de Filosofia as Instituições de Lógica e Metafísica de António Genovese, obra em que sensismo e idealismo andam de mãos dadas (2).

Também no território da filosofia jurídica se consagrou, por então, um eclectismo que combinava o jusnaturalismo de Grócio, Pufendorf, Tomásio e Wolff com inspirações empiristas e utilitaristas. Os Estatutos pombalinos impuseram, como compêndio da cadeira de Direito Natural, as Positiones de lege naturali in usum auditorum, do wolffiano Carlos António Martini. Estas Positiones, com os correctivos do comentário pró-escolástico de José Fernandes Álvares Fortuna, só seriam desbancadas em 1843, pela nova orientação kantiano-krausista introduzida na mesma cadeira por Vicente Ferrer Neto Paiva. É ainda neste período que outros estudiosos repartem desigualmente componentes empírico-sensistas ou racional-idealistas quando se dão à pesagem deste sincretismo na balança das suas preferências. Assim, a opção do fideísmo sobrenaturalista vai fazer-se, em António Soares Barbosa, mediante o repúdio dos excessos do racionalismo iluminista; a leitura psicologista do sensismo a que procede Joaquim José Rodrigues de Brito com o apoio de Villers e Degerando, implicará a refutação do inatismo idealista da corrente cartesio-leibniziana; a fundamentação utilitarista e benthamiana do racionalismo de Silvestre Pinheiro Ferreira irá processar-se através de distanciamentos referentes quer ao transcendentalismo alemão, quer ao materialismo francês (3).

(1) A obra de Condillac, embora traduzida em 1794, só seria publicada em português em 1818. Vide Ferreira Deusdado, Esboço histórico da Filosofia em Portugal no século XIX in J. M. DA Cunha SeiXas, "Princípios geraes de philosophia", Lisboa, 1898, p. IX.

(2) Veja-se em Lopes Praça, ob. cit., p. 280, nt. 1, o ofício de 23 de Fevereiro de 1773, no qual o Marquês de Pombal ordena à Universidade a rápida publicação das Instituições de Genovese.

(3) Cfr. Cabral de Moncada, Subsidios para uma história da Filosofia do Direito em Portugal (1772-1911), 2." ed., Coimbra, 1938, pp. 11-38. Vide também, 
Com a autoridade de Genovese, Heinécio e Eduardo Job (1) solidamente implantada no quadro dos nossos estudos filosóficos secundários e superiores - estes amputados, desde 1791, da cadeira de Filosofia Racional e Moral, que passara, por determinação régia, a ser professada no Colégio das Artes - e com um jusnatualismo ecléctico dando o tom aos estudos jurídicos, a produção filosófica nacional entrou em franco marasmo. De resto, a convulsão política em que Portugal mergulhara, desde os fins do século XVIII ao triunfo liberal de 1834, pouco ou nada se prestava aos afrontamentos do pensamento puro.

A reforma pedagógica de 1836, da autoria de Passos Manuel, substituindo a disciplina de Filosofia Racional, leccionada nas nossas escolas secundárias, pelas de Moral Universal e Ideologia e de Gramática Geral e Lógica, limitou-se a reafirmar o eclectismo filosófico que os vintistas haviam revigorado com os contributos da «ideologia» de Destutt de Tracy, da fisiologia de Cabanis e da moral de Volney (2).

\section{A REACÇão ideAlista E O COMBATE CONTRA GENOVESE}

A partir de 1837, começou a desenhar-se uma firme reacção contra o eclectismo sensista. Encabeçou-a, em nome do espiritualismo, Cunha Rivara, professor do liceu de Évora. Na sua Memória sobre a insuficiência do ensino de filosofia racional pelo método ordenado no decreto de 19 de Novembro de 1836, Rivara considerou inadequado ao espírito do tempo tanto o pontificado pedagógico de Genovese, Heinécio e Job, como o ideologismo de Tracy. Opinou que as nossas escolas se abrissem às correntes fecundantes do idealismo alemão, dos espiritualismos inglês (Thomas Reid e Dugald-Steward) e francês (Royer-Collard e Jouffroy) e do eclectismo cousiniano de raiz idealista (3).

sobre as estruturas do pensamento de Silvestre Pinheiro Ferreira, Josḱ EsTevEs Pereira, Silvestre Pinheiro Ferreira - o seu pensamento politico, Coimbra, 1974, pp. 81-96.

(1) A primeira edição portuguesa da Ética de Job foi impressa em Coimbra, em 1794. Cfr. Lopes PraçA, ob. cit., p. 283, nt. 1.

(2) Cfr. Newton de MACEdo, Instituições de cultura in "História de Portugal» dirigida por Damião Peres, vol. 7.', Barcelos, 1935, p. 668.

(3) Cfr. António Ferrão, Estudo sobre a filosofia em Portugal nos três primeiros quartos do século XIX in "António Cândido como pensador», Coimbra, 1924, pp. 37-39. 
O mesmo ataque era conduzido pelo próprio Silvestre Pinheiro Ferreira. Em 1839 oferecia ele à mocidade estudiosa portuguesa umas Noções elementares de Filosofia geral e aplicada às ciências morais e políticas. Ontologia, Psicologia, Ideologia, que mais não traduzem do que o firme propósito de libertar o nosso ensino da asfixiante tutela do Genuense. Escreveu Pinheiro Ferreira nessa obra: «Julgámos conveniente dar à luz estes três tratados (Ontologia, Psicologia e Ideologia) .... porque nos pareceu urgente desafrontar o ensino da Filosofia do insignificante compêndio que há mais de meio século, em vez de desenvolver, entorpece ou perverte a nascente inteligência da mocidade portuguesa» (1).

Contudo, apesar da frontalidade e veemência das objecções de Rivara e de Silvestre Pinheiro Ferreira, o Conselho Geral Director do Ensino, órgão oficial de superintendência no âmbito dos estudos secundários, preferiu pronunciar-se pela manutenção do anterior estado de coisas. Assim, em 1840, intimou o recalcitrante professor eborense a conformar-se com os compêndios de Genovese, Heinécio e Job (2). A reforma cabralista de 1844 também não trouxe novidades de maior relativamente aos conteúdos do ensino filosófico, embora inclua no seu activo a introdução nos liceus dos estudos de direito natural (3). A compendiação tradicional do conhecimento filosófico persistiu, portanto, ao longo da década de 40 , sem que contra ela se levantassem outras vozes, pese embora o menor conformismo dum Manuel António Ferreira Tavares ou dum Manuel Pinheiro de Almeida e Azevedo.

Em 1851, Manuel dos Santos Pereira Jardim, antigo professor de filosofia do liceu de Lisboa, foi encarregado pelo Conselho Superior de Instrução Pública de dar parecer sobre a projectada reforma da filosofia racional e moral e de apresentar alternativas aos programas usuais. Pereira Jardim considerou falsas e obsoletas as doutrinas de Genovese e projectou sobre as Instituições de Lógica e Metafísica um juízo radicalmente desfavorável (4). Em contrapartida, pronunciou-se

(1) Silvestre Pinheiro Ferreira, Noções elementares de philosophia geral e applicada às sciencias moraes e politicas - Ontologia, Psychologia, Ideologia, Paris, 1839, Advertência, p. VI.

(2) Cfr. Ferreira Deusdado, ob. cit., p. X.

(3) Cfr. Newton de MACEdo, ob. cit., vol. 7. ${ }^{\circ}$, pp. 666-67.

(4) «A condenação deste livro está na reprovação geral, que ele tem tido. Quanto a mim, até o nome baniria da ciência» (Manoel dos SaNtos Pereira Jardim, 
formalmente pela inclusão da "ciência de Kant, Hegel, Schelling, etc.» no âmbito dos nossos programas de ensino (1).

Não obstante a renitência dos órgãos oficiais de decisão, vai-se definindo, de Rivara a Jardim, uma linha de clivagem relativamente à predominância sensista que os Estatutos pombalinos nos tinham legado. Essa linha reivindica direitos de cidade para o idealismo em geral e sobretudo para a corrente que Kant havia inaugurado. É ela que triunfa e floresce na Faculdade de Direito, a partir de 1843, pelo magistério de Vicente Ferrer Neto Paiva.

Nos seus Elementos de direito natural, Ferrer combinou a filosofia transcendental da escola de Kant com as interpretações do krausismo, oriundas de Ahrens e Tiberghien. Renovando os estudos de direito natural e libertando-os da directa dependência do compêndio de Martini corrigido por Fortuna, Vicente Ferrer possibilitou, no plano dos princípios, a convivência de duas fundamentações jurídicas de alcance dissemelhante. A acentuação do kantismo, promovendo os direitos individuais da razão prática e autonomizando o cidadão ante a sociedade, sancionava os postulados do liberalismo burguês e abria o caminho à afirmação omnipotente dos direitos de personalidade e de propriedade. Esta filosofia jurídica, assumida com alguma continência na obra de Ferrer, viria a ecoar soberanamente no pensamento de António Luís de Seabra e a escorar o individualismo radical do nosso Código Civil de 1868. O krausismo de Ahrens e Tiberghien, pelo contrário, opunha aos defensores do «jus abutendi» e do Estado meramente arbitral e não intervencionista a concepção dum Estado corporativista e federalista, propendendo para a adopção de soluçð̃es mais conformes à noção de direito social. Foi este o trilho pisado por José Dias Ferreira, com a sua teoria do «mínimo ético», também por Martens Ferrão, com a defesa da figura do abuso do direito e sobretudo por Costa Lobo, com a sua apologia do associativismo espontâneo e orgânico dos agentes produtivos.

Ao contrário do que ocorreu em Espanha, entre nós as manifestaçð̃es do krausismo não determinaram a formação duma corrente

Relatorio e programma para a reforma da philosophia racional e moral, Coimbra, 1851, Prefácio, p. VI).

(1) «Pelo que respeita à filosofia transcendente, nada tinha que analisar, porque nem nos nossos liceus, e, o que mais é para admirar, nem na nossa própria Universidade, ainda se ensinou profissionalmente a ciência de Kant, Hegel, Schelling, etc., etc.» (Idem, p. 23). 
forte de opinião que pudesse levar ao campo da prática política o fermento de notórias transformações sociais. A sua influência, limitada ao mundo cultural universitário, não ultrapassou as balizas do diletantismo académico. Mas a escola krausista, ainda que confinada à curiosidade dos nossos intelectuais mais grados, nem por isso deixou de representar, no plano universitário, o abandono duma enraizada tradição (1). Contudo, essa tradição manteve-se e agravou-se nas nossas instituições de ensino secundário. As ciências do espírito irão aí declinar a partir dos meados do século, assistindo-se a uma contínua diminuição dos tempos de leccionação da disciplina filosófica (2). Tal degradação levou Amorim Viana, em 1853, a estigmatizar a «crassa ignorância» dos professores das nossas escolas secundárias e a lastimar que tal falta de preparação intelectual os não deixasse «distinguir os diversos elementos, aliás tão heterogéneos e inconciliáveis, com que Genovese compôs a sua inconveniente obra» (3). Foi também a consciência do nosso atraso cultural no domínio das modalidades do saber humanístico que levou José Maria de Abreu, professor da quase inerte Faculdade de Filosofia e membro do Conselho Superior de Instrução Pública, a propor ao Parlamento, em Abril de 1857, que se criassem em Lisboa e Coimbra cursos superiores de Letras. O proponente desejava ver incluídas as disciplinas de Filosofia e de História da Filosofia nos objectos curriculares desses cursos. A tentativa, embora gorada, precedeu de cerca de ano e meio a fundação, em Lisboa, do Curso Superior de Letras, por mercê régia de D. Pedro V (4).

\section{O CURSO SUPERIOR DE LETRAS E A IMPLANTAÇÃO DO CIENTISMO}

Novas esperanças se rasgaram para a cultura portuguesa com a subida ao trono de D. Pedro V. Também ele era, em certo sentido, um «estrangeirado». Durante a regência de seu pai, D. Fernando Coburgo, deambulara pelas cortes mais evoluídas da Europa, delas

(1) Vide Cabral de Moncada, ob. cit., pp. 39-86.

(2) Cfr. Newton de MACEDo, ob. cit., vol. 7.0, p. 673.

(3) AMORIM Viana, A reacção religiosa e o racionalismo, in "A Península», apud António Ferrão, ob. cit., p. 57.

(4) Cfr. Newton de MACEDo, ob. cit., vol. 7. ${ }^{\circ}$, pp. 672-73. 
trazendo a aflitiva constatação do fosso intelectual que nos separava do poderoso progresso intelectual transpirenaico (1). Atento, na ordem mental, aos sinais dos tempo se às inflexões das teorias, o monarca concluía que as causas mais fundas da nossa incipiência espiritual tinham que ver, em primeira linha, com a decadência das nossas instituiçð̃es de cultura (2). O Curso Superior de Letras nasceu deste complexo de preocupações, através dum acto de munificência real: por decreto de 30 de Outubro de 1858, o jovem monarca permitiu que se deduzisse da sua lista civil a importância de trinta contos de réis, para que passassem a funcionar, em Lisboa, segundo os termos do referido diploma, «cursos públicos de História, de Literatura Antiga e de Literatura Moderna, particularmente da portuguesa». Ficavam, assim, parcialmente satisfeitos os anelos de José Maria de Abreu.

A intenção do monarca era que a recém-criada instituição se convertesse futuramente numa verdadeira Faculdade de Letras, através

(1) Em 1854 e 1855, o jovem príncipe peregrinou pela Inglaterra, França, Bélgica, Itália, Alemanha e Áustria, num périplo de estudo que lhe permitiu cotejar o grau de evolução das paragens visitadas com as mais modestas realidades do país natal.

(2) D. Pedro $\mathrm{V}$ foi, seguramente, o mais brilhante dos monarcas brigantinos. O mais implacável adversário da dinastia, Teófilo Braga, não deixou de lhe prestar homenagem ao referir o seu pensamento «luminoso e prático» e ao considerá-lo um «jovem monarca esclarecido de espírito e dotado de boa vontade» (TeófiLo Braga, Noticia histórica desde a fundação do Curso Superior de Lettras até ao presente in BusqueTs De Aguilar, «O Curso Superior de Letras (1858-1911)». Intelectual introvertido e melancólico, acreditando mais no poder das ideias do que nas agitações da baixa política, viria a ser considerado pelo seu mais devotado biógrafo como o «primeiro homem moderno do nosso país» e o "verdadeiro precursor da geração de 70" (Ruben Andresen Lertão, D. Pedro V e a sua época in "Cartas de D. Pedro V aos seus contemporâneos», Lisboa, 1961, p. 47). A sua actualização de perspectivas afere-se pelo seguinte excerto da carta que dirigiu, em Março de 1855, ao Marquês de Ficalho: "Conformo-me muito com os tempos em que vivo, .... pertenço ao positivismo e adopto plenamente o programa moral da gente sensata dos últimos tempos. Entrego-me a estudos que me parecem ser o que a tendência dos meus dias reclama....) (Carta de 22 de Março de 1855, de D. Pedro V ao Marquês de Ficalho in RUBEN ANDRESEN LeITÃo, ob. cit., p. 104). Assim, não é de admirar que o jovem rei tenha colocado na primeira linha das suas preocupações o problema da revitalização do nosso ensino público: «Não sei se muitos se preocupam com o estudo actual e com o futuro deste último. Eu muito: vejo-o, decaindo diariamente, vejo, que se lhe secaram as raizes, e que assim, se lhe foi a virtude prolifica" (Carta de 31 de Outubro de 1858, de D. Pedro V ao Ministro da Fazenda, António José de Avila in Busquets de Aguilar, ob. cit., p. 10). 
dum progressivo alargamento do elenco de cadeiras aí p ofessadas (1). Contudo, este voto aguardaria mais de meio século para se cumprir. Com efeito, só depois da revolução republicana, em Maio de 1911, sob a iniciativa do governo provisório de Teófilo Braga, foi possível assistir à criação da Faculdade de Letras da Universidade de Lisboa, herdeira natural do Curso Superior de Letras.

As disciplinas filosóficas não constavam do currículo de estudos inicialmente patrocinado pelo mecenato régio. Mas logo no ano seguinte, por carta de lei de 8 de Junho de 1859 , se incluíram no quadro das cadeiras leccionáveis a Filosofia e a História Universal Filosófica. Notemos que, ao tempo, as filosofias que vingavam em Portugal se repartiam entre o eclectismo francês e o idealismo germânico. Os pensadores vulgarizados entre nós eram, então, Maine de Biran, Jouffroy, Cousin, Kant, Schelling, Royer-Collard. No concurso de 1860 de acesso à docência da cadeira de Filosofia do Curso Superior de Letras, o tema obrigatório foi o das relaçð̃es existentes entre o eclectismo de Cousin e a filosofia alemã, o que comprova ser este o sustentáculo fundamental da «forma mentis» filosófica nacional (2). Perto destas orientaçð̃es andaram também os professores que nessa instituição regeram, até aos finais do século, as disciplinas filosóficas: tanto Levi Maria Jordão, como Costa Lobo, como ainda Jaime Moniz se integravam na corrente krausista que Ferrer havia introduzido nos estudos jurídicos de Coimbra (3).

Entre 1860 e 1880, o panorama do pensamento português conheceu substanciais modificações. A melhoria e alargamento das vias de

(1) «A Faculdade de Letras aí a deixo esboçada, incompleta, é verdade, mas tal que já não são capazes de deixar de ma completar. Ponho-a a bater-lhes à porta. e tão de rijo o há-de ela fazer, que não hão-de poder menos de abrir-lha» (Idem).

(2) Cfr. Adolfo Coelho, Le Cours Supérieur de Lettres, Paris-Lisbonne, 1900, pp. 19-21.

(3) O Visconde de Paiva Manso, Levi Maria Jordão, foi grandemente influenciado por Röder, discípulo de Krause, defendendo numa dissertação de 1853 , sobre $O$ fundamento do direito de punir, um organicismo metafísico de inconfundível ressaibo krausista. À noção de corporativismo orgânico, defendida por Costa Lobo ao recomendar a livre e pacífica associação das forças produtivas, não é também estranha a mensagem do krausismo. Finalmente, o próprio Jaime Moniz se deixou contagiar pelas ideias de Krause, encarando, na sua memória de habilitação à docência sobre a Natureza e extensão do Progresso considerado como lei da Humanidade, a evolução universal como algo comparável ao crescimento contínuo dum organismo (Cfr. Cabral de Moncada, ob. cit., pp. 62-64, 74-82 e p. 76, nt. 1). 
comunicação, resultantes da política de fomento do fontismo, muito contribuíram para a superação dum isolamento ancestral e para a facilitação de contactos com universos culturais até aqui insuspeitados. Entram de rompante, nas tertúlias académicas marginais à cultura oficial, os contributos da escola exegética de Strauss, do cientismo de Renan, do evolucionismo de Spencer; apreendem-se as novas concepções historiográficas de Quinet e Michelet; discute-se a Filosofia da Arte de Taine e a metodologia científica de Claude Bernard; discorre-se sobre a visão socializante de Fourier e Proudhon. O positivismo, essa inevitável matriz do pensamento científico e social da segunda metade do século XIX, faz o seu aparecimento entre nós, primeiramente sob a forma duma filosofia da matemática, depois, mais sistematicamente, através da pedagogia jurídica de Manuel Emídio Garcia, na sua regência coimbrã de Direito Administrativo (1).

A acirrada polémica que Antero de Quental despoletou em 1865 com a publicação do seu opúsculo Bom senso e bom gosto e que passou à história sob a designação de "Questão Coimbrã», constituíu um dos primeiros sintomas da renovação mental que se ia processando. Não se tratava apenas de dissentir das fórmulas dessoradas dum ultra-romantismo literário. $\mathrm{O}$ próprio Antero lhe atribuíu um claríssimo significado filosófico quando, fazendo muito depois o balanço da discussão, disse que, após a dissipação do fumo gerado pela disputa, «o que se viu mais claramente foi que havia em Portugal um grupo de dezasseis a vinte rapazes .... que já não eram católicos nem monárquicos, que falavam de Goethe e Hegel, como os velhos tinham falado de Chateaubriand e de Cousin; e de Michelet e Proudhon, como os outros de Guizot e Bastiat» (2). De resto, foi também nesse mesmo ano de 1865 que Antero defendeu a necessidade duma nova síntese filosófica, operada a partir dos pensamentos de Comte, Renan, Vacherot e Stuart Mill.

As raízes deste novo cientismo naturalista firmam-se entre 1870 e 1880. Logo no começo da década, em 1871, esta corrente tinha aflorado nas formulações contestatárias e potencialmente revolucioná-

(1) Cfr. Fernando de Almeida Catroga, Os inicios do positivismo em Portugal - o seu significado politico-cultural, in "Revista de História das Ideias», vol. 1., Coimbra, 1977, pp. 27-29.

(2) ANTERo De Quental, Carta autobiográfica a Wilhelm Storck, de 14 de Maio de 1887, in «Cartas de Anthero de Quental», 2. ${ }^{\text {a }}$ edição, Coimbra, 1921, pp. 5-6. 
rias das «Conferências Democráticas» do Casino Lisbonense. Inicialmente, a leitura hegeliana do movimento do Ser e a lei spenceriana do progresso, entendido como modalidade de passagem do homogéneo para o heterogéneo, ainda suportam a moldura metafísica do Absoluto e do Incognoscível. Porém, cedo a fundamentação filosófica alijará estes últimos resquícios de transcendência, encaminhando-se para mais decantados horizontes monístico-materialistas. O positivismo de Teófilo, por exemplo, longe de se manter fiel à ortodoxia comteana -- ou mesmo littreana - caldear-se-á com o sincretismo das mesologias visceralmente materialistas provenientes de Lamarck, Darwin e Haeckel. Os seus Traços gerais da filosofia positiva já se integram nesta óptica. É também ela que se encontra presente nos escritos da maior parte dos colaboradores da revista $O$ Positivismo, dirigida por Teófilo e Júlio de Matos, a qual funcionou como órgão aglutinador dos defensores da nova corrente (1).

O Curso Superior de Letras não se manteve à margem das convulsões culturais entretanto verificadas. A corrente krausista, a que aludimos, viu-se forçada a coexistir com a leitura materialista do positivismo, mediante o acesso à docência de alguns professores que já se tinham salientado pelo seu inconformismo intelectual. Dentre eles, destacam-se os nomes de Augusto Soromenho, Adolfo Coelho, Vasconcelos de Abreu e Teófilo Braga. Recordemos que os dois primeiros tinham tomado parte activa nas controversas "Conferências do Casino", assinando com Teófilo o manifesto divulgador das mesmas e nelas proferindo alocuçð̃es. Também Vasconcelos de Abreu se solidarizou inicialmente com Teófilo Braga, quando este pretendeu que o núcleo escolar fundado por D. Pedro V se convertesse numa Faculdade de Sociologia, em conformidade com as perspectivas comteanas (2). Foi, de resto, sob a influência destes pedagogos que o Curso Superior de Letras veio a associar-se a iniciativas públicas dinamizadas pela opinião republicana com a manifesta intenção de se levar por diante

(1) Alguns dos artigos insertos na revista $O$ Positivismo explicitam nos próprios títulos a derivação filosófica de que se nutrem os seus autores. Citamos, um tanto ao acaso, o Ensaio sobre a evolução em biologia, de Júlio de Matos (vide «O Positivismo", n. ${ }^{\circ s} 2,3$ e 4, 1. Ano, Porto, 1879); a Seleç̧ão natural em sociologia, de Horácio Ferrari (idem, n. ${ }^{\circ}$ 2); o Principio da evolução e a lei de Baer, de Cândido de Pinho (idem, n. ${ }^{\circ}$ ) e, finalmente, o pequeno artigo em que Ernesto Cabrita apresenta Mais uma prova em favor do transformismo (idem, n. ${ }^{\circ}$ ).

(2) Cfr. Busquets de Aguiar, ob. cit., pp. 102-105. 
o trabalho de demolição institucional que já se vinha realizando na esfera do cultural. Assim, o Curso fez-se representar tanto nas comemorações camoneanas de 1880 como nas festas do centenário pombalino, em 1882.

Contudo, a corrente krausista manteve-se inalterada no que concerne à cadeira de Filosofia professada na instituição, enquanto Costa Lobo a ministrou. A situação modificou-se, contudo, com o seu falecimento. A vaga assim deixada em aberto foi preenchida por Joaquim António da Silva Cordeiro, em Janeiro de 1902. É ao estudo do seu ideário filosófico e político que iremos consagrar as próximas páginas.

\section{II -- O POSITIVISMO NA OBRA DE JOAQUIM ANTÓNIO DA SILVA CORDEIRO}

\section{A SUPERAÇÃO DO KRAUSISMO NO CURSO SUPERIOR DE LETRAS}

Joaquim António da Silva Cordeiro iniciou a sua carreira profissional como professor contratado do ensino liceal, depois de se ter bacharelado em Direito na Universidade de Coimbra. Ascendeu posteriormente, como já foi dito, à docência da cadeira de Filosofia do Curso Superior de Letras. Natural de Braga, firmara nos seus tempos de estudante universitário uma sólida reputação científica, fazendo imprimir na revista conimbricense $O$ Instituto, durante os anos de 1884 e de 1885, alguns trabalhos meritórios (1). A sua atenção privilegiava então os estudos jurídicos e económicos. Mas já anteriormente reflectira sobre a temática filosófica. Os seus Ensaios de philosophia da história, obra surpreendente pela elegância literária e pela solidez científica, foram impressos em 1882, quando o seu autor era apenas um estudante do segundo ano do curso em que se viria a bacharelar.

Analisados de perto, os Ensaios revelam-nos que Cordeiro não se manteve indiferente à sedução de algumas das mais básicas propostas positivistas. Aí analisa criticamente as filosofias da história de Bossuet,

(1) Vide JoAquim António da Silva Cordeiro, Systemas sobre a base do imposto in «O Instituto», t. 31, Coimbra, 1884, pp. 165-177; Liberdade commercial, t. 32, Coimbra, 1885, pp. 235-43 e 333-43. Publicou também, em 1885, umas Questões de finanças, pequena obra de conteúdo técnico-jurídico que, à semelhança das anteriormente citadas, nada permite adiantar sobre o seu posicionamento filosófico. 
Vico, Montesquieu, Turgot, Condorcet e Voltaire. Silva Cordeiro anunciava nesta obra a intenção de tratar, num volume a aparecer posteriormente, das filosofias da história «das escolas alemãs desde Kant até Hartmann, e dos trabalhos históricos da actual escola positiva, que tem em Spencer o seu último representante» (1). O projecto não chegou a tomar corpo, pelo que se encontra vedada a possibilidade de apuramento directo da amplitude da referência positivista no conspecto do seu pensamento. Os Ensaios abordam, porém, teorizaçðes sobre a filosofia da história que foram reconhecidas pelo próprio Comte como prolegómenos necessários do positivismo, estando neste caso as de Montesquieu, Turgot e Condorcet. Nessa abordagem é bem sensível a influência sobre o jovem estudante dos critérios e valoraçð̌es do autor do Curso de Filosofia Positiva.

Em 1896, Cordeiro publicou uma outra obra cuja concepção nada tem já que ver com a feição radicalmente especulativa dos Ensaios: A crise em seus aspectos moraes. Foi intenção do seu autor fazer, através dela, o «balanço moral dos últimos vinte anos» (2). Pelo seu cariz de empenhamento e de intervenção política, este escrito bem poderá ombrear com todos os que, na fase final da dinastia brigantina, contribuíram para o descrédito total do constitucionalismo monárquico.

Cordeiro supera, nesta sua obra de maturidade, as adjunçð̃es positivistas dos Ensaios ou, se quisermos apelar para a feliz expressão de Álvaro Ribeiro, transita subtilmente «da ideologia positivista para a sociologia realista». Ora esta «sociologia realista», de que nos fala Álvaro Ribeiro, confunde-se com o propósito socializante dum Proudhon ou dum Lassalle (3).

Do ponto de vista filosófico, o que mais nos importa assinalar é que o ingresso de Silva Cordeiro no Curso Superior de Letras se teria saldado, segundo toda a probabilidade, pela completa extirpação da metafísica krausista, tão acarinhada pelo seu antecessor. Não se vislumbram vestígios dela, nem nos Ensaios, nem em $A$ crise. Pelo contrário, o que dessas obras ressalta é, quanto à primeira, uma noção de filosofia da história tributária do positivismo comteano; e, quanto à

(1) Idem, Ensaios de philosophia da historia. I-Exame critico dos systemas, Coimbra, 1882, Preliminares, p. XI.

(2) Idem, A crise em seus aspectos moraes - Introducção a uma bibliotheca de psychologia individual e collectiva, Coimbra, 1896, p. 18.

(3) Cfr. Álvaro Ribeiro, Os positivistas, Lisboa, 1951, pp. 95-97. 
segunda, uma superação do sistema político positivista em nome das reclamações provenientes do horizonte socialista.

Disto nos ocuparemos seguidamente.

\section{SILVA CORDEIRO E A FILOSOFIA DA HISTÓRIA}

A noção de progresso, teorizada pelos iluministas, ocupou um lugar de grande preponderância nos sistemas de pensamento de quantos se propuseram, no decurso da primeira metade do século XIX, encontrar as normas explicativas da perfectibilidade humana e fundar a nova ciência do homem. Adquirida que foi, por via do mero discurso retórico, a certeza do avanço do espírito humano, tornou-se imperativo conferir a tal noção, até então simplesmente intuída, o estatuto de verdade demonstrada. Fundamentalmente, foram três os modelos em que se basearam tais demonstrações: o das ciências matemáticas, o das disciplinas económicas e o dos conhecimentos físico-biológicos.

A primeira orientação foi preconizada por Turgot, Condorcet, Laplace, Lacroix e, mais tardiamente, por Désiré Le Moyne. Confiava-se na eficácia preditiva do cálculo de probabilidades e da estatística e esperava-se que a exactidão do quantitativo pudesse conferir às chamadas «artes sociais» uma dimensão de plenitude científica, expurgando-as da sua atávica subjectividade (1).

O primado do económico no âmbito do social e do político e a sua hegemonia no interior das «ciências morais» reconhece-se em Saint-Simon, o qual, sobretudo no período da sua apologética industrialista, não regateava elogios ao pensamento fisiocrático e à obra de Say.

Contudo, foram as sugestões do organicismo biologista, articuladas com tributações de tipo fisicalista, que mais profundamente marcaram os fundadores da sociologia. Tanto Comte como Saint-Simon acolheram de bom grado os resultados apurados por Cabanis, Bichat, Gall, Broussais, etc. A perfectibilidade humana não resultava, para eles, da admissão apriorística duma qualquer razão pura, fazendo-a

(1) Exemplificam esta metodologia os Eléments du calcul des probabilités et son application aux jeux de hasard, à la loterie et aux jugements des hommes, avec un discours sur les avantages des mathématiques sociales, de Condorcet, o Essai philosophique sur les probabilités, de Lacroix e as Dissertations politiques et philosophiques sur les principes du gouvernement, de Désiré le Moyne. 
antes depender do maior grau de complexidade da organização material da espécie. Estabeleciam, desta maneira, uma intrínseca continuidade entre as disciplinas que tratavam dos corpos brutos e as que se ocupavam dos corpos organizados. A física, percorrendo a escala dos corpos simples e elevando-se à consideração progressiva dos mais complexos, desembocava numa fisiologia. Deste modo se operava uma totalização e unificação sistemática da experiência, no interior da qual avultava a submissão ôntica do organizado à legalidade do desorganizado.

Foi este o modelo de análise que permitiu a Saint-Simon, sob as influências conjuntas de Burdin, Vicq d'Azur, Bougon e Oelsner, transpor para os domínios do moral e do social a lei da atracção universal de Newton, ousando colocar o princípio da gravitação no lugar de Deus (1).

Iremos encontrar os mesmos postulados na enciclopédia científica de Augusto Comte. A lógica em que assentava a sua classificação conduzia-nos do mais simples ao mais complexo, do menos organizado ao mais organizado, da matéria bruta à matéria viva, e pressupunha uma hierarquia de leis que complicavam progressivamente os domínios subordinados. Esta sujeição lógica determinava o momento cronológico da emergência positiva das disciplinas sucessivamente consideradas e justificava o tardio advento da sociologia. Com efeito, houve que aguardar a plena cientificação dos saberes propedêuticos - matemáticos, astronómicos, físico-químicos e biológicos - para que se pudesse erigir, só então, com plena segurança de critério e de metodologia, o edifício sociológico.

Encontramos aqui uma importante clivagem entre a tentativa saint-simoniana de constituição da "ciência do homem»e a proposta comteana: enquanto que a sintese do primeiro se pretendeu fazer por redução da fenomenologia geral ao princípio universal da gravitação, a sintese do segundo operou-se através da subordinação das categorias enciclopédicas consideradas (2). A sociologia aparecerá, desta maneira, na economia do pensamento de Comte, como uma instância subordinada

(1) Leiam-se os trabalhos publicados por Saint-Simon entre 1802 e 1813 , especialmente as Lettres d'un habitant de Genève, a Mémoire sur la science de l'homme e a Introduction aux travaux scientifiques du XIX.a siecle. Vide também HeNRI Gounier, La jeunesse d'Auguste Comte et la formation du positivisme II - Saint-Simon jusqu'à la Restauration, Paris, 1936, pp. 180-222 e 324-32.

(2) Cfr. Georges BAstiDe, Les grands thèmes moraux de la civilisation occidentale, Paris, 1958, pp. 204-11. 
a categorias científicas propedêuticas e especializadas. Mas este apenas é o seu estatuto se nos ativermos ao espaço objectivo que lhe legitimou a emergência. Porém, Augusto Comte sempre protestou contra o culto "dispersivo», compartimentado e estéril das ciências particulares. Mais importante que a ordem objectiva é a ordem subjectiva. Mais significativo que o espírito de detalhe é o espírito de conjunto. Mais representativo que o ponto de vista técnico é o ponto de vista humano. Quando o cientista abandona o pequeno jardim da sua especialidade e enverga a roupagem de filósofo das ciências, vê-se forçado a reconhecer que a própria relação de subordinação se encontra invertida, ou seja, que é na Humanidade e na ciência que lhe respeita, a Sociologia, que se encontra o princípio sintético da classificação científica. Poderá então declarar que todas as ciências são factos sociológicos, já que o homem se encontra de corpo inteiro no menor dos teoremas ou dos axiomas particulares. Esse envolvimento da espécie humana na teorização e axiomatização científicas verifica-se porque cada domínio científico, por mais simples ou por mais complexo que seja, reproduz, no seu processo de formação e de desenvolvimento, a própria legalidade do processo histórico de cognição do espírito humano. A história de cada ciência espelha, desta maneira, a própria aventura do sujeito cognoscente e as sucessivas fases ou estados da sua evolução (1).

A constituição diacrónica das ciências da tábua enciclopédica não resultava da descoberta, em momentos distintos, de novas pistas cognitivas ou de novos critérios de legalidade epistemológica. Antes se tratava de subineter ao mesmo processo de legalidade espiritual as esferas de realidade e as zonas de conhecimento tornadas mais complexas pela sucessiva implicação, no domínio considerado, de variáveis científicas já anteriormente averiguadas, às quais acresciam as que lhe eram próprias e se encontravam por inquirir.

O progresso comteano identificava-se, portanto, com a própria história intelectual da espécie, no afadigado labor de se apropriar cognitivamente de parcelas de realidade crescentemente complicadas. Esta apropriação cognitiva realizava-se quando o espírito humano submetia o ilusório painel das suas explicações imaginárias ao império definitivo da observação e da verificação. O antropomorfismo das

(1) Cfr. Alain, Idées. Introduction à la philosophie-Platon, Descartes, Hegel, Comte, Paris, 1939, pp. 305-7 e LÉvy-BruHL, La philosophie d'Auguste Comte, Paris, 1900, pp. 25-38. 
explicações teológicas e o essencialismo das explicaçðes metafísicas cediam o passo ao realismo das demonstrações positivas. Sendo assim, era pela análise da história das ciências que se tornava possível apurar com exactidão o grau actual do desenvolvimento do espírito. Este, no seu imparável movimento, conferira já foros de positividade a quase todas as regiōes do conhecimento, deixando apenas de fora as realidades humanas morais e sociais. Tratava-se agora de submeter ao império do espírito positivo este último baluarte de resistência, superando, também aqui, a hegemonia dos assertos teológico-metafísicos. Só então, reduzidas a um mesmo espírito todas as disciplinas da tábua enciclopédica, ficaria definitivamente comprovada a inteira coincidência entre a filosofia da história e a filosofia das ciências (1).

Converter a sociologia em disciplina científica era fazer dela, à semelhança das demais, uma ciência de factos e não de dogmas. Para isso, o teorizador teria de prescindir da consideração da metafísica causalitária, passando a ocupar-se unicamente com o modo de produção dos fenómenos que inquiria. A indagação das causas cederia o lugar à perquirição das leis e a ordem do porquê franquearia o passo à ordem do como. A esfera do moral e do político, desembaraçada da carga ancestral do providencialismo teológico e do naturalismo metafísico, ofereceria ao cientista a matéria prima da sua singela factualidade, para que ele a fecundasse com a seiva do seu realismo observador e experimental (2).

Comte reconheceu que esta esperança de constituir um saber positivo do universo moral e de apoiar sobre este conhecimento uma acção política esclarecida fora já acalentada por alguns predecessores. Dentre eles, atribuíu especial importância a Montesquieu e Condorcet. Sabemos que o filósofo positivista leu atentamente as Considérations sur les causes de la grandeur des romains et sur leur décadence, as Lettres persannes e sobretudo L'Esprit des lois. Agradou-lhe sobremaneira que a abordagem do social e do político fosse feita, nessas obras, em

(1) Cfr. Henri Gouhier, La jeunesse d'Auguste Comte... III-Auguste Comte et Saint-Simon, Paris, 1941, pp. 296-300.

(2) «En un mot, la révolution fondamentale qui caractérise la virilité de notre intelligence consiste essentiellement à substituer partout, à l'inaccessible détermination des causes proprement dites, la simple recherche des lois, c'est-à-dire, des relations constantes qui existent entre les phénomènes observés» (СомтE, Discours surl'esprit positif in «Oeuvres d'Auguste Comte», t. 11. ${ }^{\circ}$, Paris 1969-70, p. 13). 
termos de objectividade e de realismo analítico. Pareceu-lhe acertado, embora também um tanto excessivo, o relevo dado por Montesquieu a factores empíricos climáticos e mesológicos. Daí que tenha encarado a sua obra como um dos mais logrados esforços para fazer da política uma ciência. A sua admiração por Condorcet era ainda maior. No Esquisse d'un tableau historique des progrès de l'esprit humain estaria traçada a via metodológica preferencial para a inferência indutiva da lei natural progressiva a que se encontraria submetida a marcha necessária da civilização. Por isso o reconheceu como seu «predecessor imediato» e «verdadeiro pai espiritual» $\left({ }^{1}\right)$.

Não obstante, considerou abortados e prematuros os empreendimentos teóricos dum e doutro. Ambos asseveravam a necessidade da descoberta da legalidade sócio-natural sem que, contudo, nenhum deles tivesse podido superar o nível dum empirismo ingénuo, incapaz de ir além duma circunstancial e artificial aproximação de factos civilizacionais (2).

Estas perspectivas sobre a filosofia da história encontraram o mais franco acolhimento nos Ensaios de Silva Cordeiro. As laboriosas cogitações histórico-filosóficas só teriam utilidade, em sua opinião, se fossem capazes de "estudar a marcha ascensional e evolutiva da civilização, trasladar os factos à plena luz dos princípios e leis que os dominam, formular essas leis, verificá-las experimentalmente, e, apertando em explêndida síntese as gerações e os factos que assinalaram a sua passagem, iluminar com as fulguraç̃es radiosas dessa síntese a desenvolução futura dos povos» (3). Tal como Comte, Cordeiro

(1) Sobre a enorme importância que Comte atribui às tentativas de Montesquieu e Condorcet para a definitiva constituição duma "fisica social», leia-se o Plan des travaux scientifiques nécessaires pour réorganiser la société, in «Oeuvres d'Auguste Comte», t. $10 .^{\circ}$, Paris, 1970, pp. 106-110 e a 47. a lição do Cours de philosophie positive, in "Oeuvres d'Auguste Comte», t. 4. ${ }^{\circ}$, Paris, 1969, pp. 190-209. Desta última obra extraímos a seguinte passagem: "Les deux tentatives philosophiques que je viens de caractériser sommairement sont, à vrai dire, les seules jusqu'ici qui, malgré leur irrécusable précocité et leur inévitable avortement, doivent être envisagées comme dirigées suivant la véritable voie générale qui peut conduire finalement à la constitution positive de la science sociale» (p. 209).

(2) A crítica que Comte dirige a Condorcet é igualmente aplicável à metodologia de Montesquieu: «Il a cru pouvoir coordonner convenablement les faits en prenant presque au hasard, pour origine de chaque époque, un événement remarquable, tantôt industriel, tantôt scientifique, tantôt politique». (CомтE, Plan des travaux... in ob. cit., t. 10. ${ }^{\circ}$, p. 110).

(3) Silva Cordeiro, Ensaios..., p. 5. 
julgou ser possível desentranhar do profuso material histórico acumulado pela marcha das gerações uma «lei histórica indutiva» (1), uma «lei típica» (2), susceptível de silenciar definitivamente "os obstinados da filosofia da história, que ainda se recusam a crer na possibilidade de previsão científica pelos processos experimentais» (3). Por outro lado, recusando embora ao sistema comteano uma obediência estrita (4), o autor dos Ensaios assinalava também à evolução científica um ritmo triádico e ascendente. Os períodos fenomenal ou empírico, crítico ou classificativo e filosófico ou científico, de que nos fala, são patamares de desenvolvimento através dos quais a razão "vai elaborando sínteses cada vez mais amplas, até descobrir a lei que regula e consubstancia a evolução natural dos fenómenos» (5). Silva Cordeiro referia ainda a ideia de progresso a um sujeito uno, idêntico e contínuo, ou seja, a uma Humanidade capitalizadora dos resultados teórico-práticos de geraçð̃es sucessivas. Ora esta noção de hereditariedade social exprimia-se frontalmente nas obras de Turgot e Comte.

A influência positivista é ainda mais transparente no tratamento dado por Silva Cordeiro ao sistema de Condorcet. Ele próprio confessou que a maior parte das suas observações eram «deduzidas da judiciosa apreciação que Augusto Comte fez das teorias sociais de Condorcet, levemente modificadas pelos correctivos de Littré» (6). Tal como o positivista francês, Cordeiro considerou o Tableau como um esboço conjectural de grande importância, sem o qual poderia ficar seriamente comprometido ou longamente adiado o projecto de inferência de leis sociais positivas (7). Mas rejeitou também, em perfeita consonância com os reparos comteanos, a filiação histórica dos dados de civilização com que Condorcet construíu a sua periodização, considerando que eles não nasceriam uns dos outros «por um crescimento natural de intuscepção», mas teriam sido «escolhidos a esmo», na ausência dum «princípio superior» que os pudesse sintetizar $\left.{ }^{(}\right)$.

(1) Idem, p. 106.

(2) Idem, p. 53.

(3) Idem, p. 102

(4) «A. Comte .... que eu gosto de citar todas as vezes que o seu génio o não transvia em apreciações sistemáticas....». (Idem, p. 125, nt. 1).

(5) Idem, p. 45.

(6) Idem, p. 211, nt. 1.

(7) Cfr. idem, p. 225.

(8) Idem, pp. 218-19. 
A filosofia positivista da história, ao naturalizar o domínio histórico-social e ao submetê-lo a um processo de legalização em tudo semelhante ao das ciências exactas, expulsou do seu âmbito a interferência divina em que se baseavam as interpretações teológicas da desenvolução social. Daí que não surpreenda que Bossuet apareça apontado na obra de Cordeiro como o «derradeiro campeão duma filosofia exausta» ( $\left.{ }^{1}\right)$. Repudia-se, assim, "a ideia de uma providência descaroavel, que pune exterminando e aniquilando» e pressagia-se que a ideia providencialista, a «ideia sanguinária dos De Maistre e De Bonald será pouco e pouco banida da cenografia histórica, à medida que .... for provocando na escola racionalista uma reacção cada vez mais enérgica e tenaz» (2).

Com o que ficou dito, parece ter ficado ilustrada a filiação positivista da filosofia da história a que então aderia o jovem Joaquim António da Silva Cordeiro.

\section{O PENSAMENTO POLítico DE SILVA CORDEIRO}

A pretensão comteana de converter a política numa ciência rigorosa flui com toda a naturalidade dos pressupostos teleológicos em que radica a lei dos três estados. A cada estado de conhecimento a que a espécie humana se encontra adstrita corresponde uma forma típica de organização social. Sob o império da forma teológica dos conhecimentos, são estados teocrático-militares que se organizam. Porém, quando a autoridade dos chefes militares e dos hierarcas religiosos foi posta em causa, surgiram as irrupç̃es dissolventes e críticas do individualismo. A plácida e indisputável Ordem de outrora passou a ser substituída pela crença num Progresso caucionado pela liberdade pessoal de consciência e pelo princípio da soberania popular. O movimento que dissolveu o autoritarismo anterior iniciou-se sob a Reforma protestante e culminou com a convulsão política da Revolução Francesa de 1789.

No entanto, os regimes que se sucederam no fluxo do tempo não receberam a sua consagração do mero voluntarismo dos agentes histó-

(1) Idem, p. 78.

(2) Idem, p. 77. 
ricos, não podendo, consequentemente, ser encarados como produções autónomas do talento individual personificado nesta ou naquela figura. Antes obedeceram, na sua implantação e afirmação histórica, à mesma lei inelutável de desenvolvimento que serviu de base à transformação da consciência cognoscente da Humanidade (1). Releva aqui a ideia leibniziana dum passado prenhe de actualizáveis potencialidades e dum presente prefigurador do figurino futuro (2). Pecaria contra a legalidade do tempo qualquer teorização que caprichasse em desconhecer a irreversibilidade do processo histórico-político e teimasse quer no retorno a fórmulas políticas esgotadas, quer na pulverização, em nome dum progresso mítico, dos estádios intermediários duma evolução necessariamente lenta $\left({ }^{3}\right)$.

Quando Comte iniciou a publicação das suas obras, em 1824, com o Prospectus des travaux scientifiques nécessaires pour réorganiser la société, as tendências políticas em voga oscilavam entre o organicismo agónico da teocracia tradicionalista de Joseph de Maistre e Bonald e o criticismo dos Enciclopedistas, que ele considerava revolucionário e anarquizante. Quaisquer destas correntes se mostrava incapaz, no seu entender, de encerrar o ciclo revolucionário. A primeira porque, fazendo tábua rasa do processo evolutivo entretanto cumprido, pretendia o retorno a uma fase de imobilismo sepultada no passado mais remoto, fixando-se no culto duma Ordem cristalizada e infecunda; a segunda porque, fascinada pela miragem da revolução permanente, aplaudia um Progresso que desconhecia as suas raízes históricas e os ritmos normativos da sua progressão. Pelo contrário, o projecto positivista, reconhecendo e assumindo o processo inelutável das filiações históricas, convertia a política numa simples ciência de

(1) «.... la loi supérieure des progrès de l'esprit humain entraîne et domine tout; les hommes ne sont pour elle que des instruments .... Tout ce que nous pouvons, c'est d'obéir à cette loi (notre véritable providence), avec connaissance de cause, en nous rendant compte de la marche qu'elle nous prescrit...) (СомтE, Sommaire appréciation de l'ensemble du passé moderne, in ob. cit., t. 10.0, p. 24).

(2) «.... le véritable esprit général de la sociologie dynamique consiste à concevoir chacun de ces états sociaux consécutifs comme le résultat nécessaire du précédent et le moteur indispensable du suivant, selon le lumineux axiome du grand Leibniz: Le présent est gros de l'avenir» (СомTE, Cours..., in ob. cit., t. 4. ${ }^{\circ}$, p. 292).

(3) «.... la marche de la civilisation .... est donc essentiellement inaltérable, quant au fond. En termes plus précis, aucun des degrés intermédiaires qu'elle fixe ne peut être franchi, et aucun pas rétrograde véritable ne peut être fait.» (CомTE, Plan des travaux.... in ob. cit., t. 10. ${ }^{\circ}$, p. 93). 
aplicação das leis já averiguadas pela sociologia. Deste modo, o político positivista não poderá alimentar quaisquer pretensð̃es de criatividade (1). Limitar-se-á a ser, mais modestamente, o simples gestor daquele património previsional deposto nas suas mãos pelo prévio apuramento da legalidade sociológica. Operando num mundo em lenta mas inevitável transformação, o político positivista não arbitrará livremente os termos da alteração política ou o sentido do desenvolvimento. O prévio conhecimento teórico das leis do desenvolvimento social permitir-lhe-á detectar, em cada momento, a «tendência da civilização», à qual facilitará a plena emergência, introduzindo no tecido social o conjunto de transformações requeridas por uma evolução que deve seguir o caminho da menor resistência e fazer-se "por meios doces e fáceis». O político positivista será, deste modo, o parteiro sereno do amanhã (2).

Sendo assim, o discurso positivista pretende apresentar-se como não revolucionário. A revolução, enquanto manifestação patológica do corpo social, só poderá manifestar-se pela inércia de acção ou inépcia de avaliação dos políticos empíricos. Em última análise, as manifestações revolucionárias só ocorrem porque os homens públicos, ignorando a legalidade do processo teleológico a que se encontra submetido o evoluir social, lhe desnaturam, na sua acção prática, as regras naturais de desenvolvimento (3). Augusto Comte sustenta que a ordem do processo histórico-natural, desde que não desvirtuada pela interferência abusiva duma qualquer desajeitada aç̧ão prática, desemboca num progresso que é dela a inevitável consequência. Progredir

(1) De resto, decorre daqui a avultante superioridade da política positiva sobre as políticas teológica e metafísica: «Cette supériorité résulte de ce qu'elle découvre ce que les autres inventent» (Idem, pp. 100-101).

(2) «La donnée fondamentale de la politique pratique générale, son point de départ positif, est donc la détermination de la tendence de la civilisation, afin d'y conformer l'action politique, et de rendre par là aussi douces et aussi courtes que possibles les crises inévitables auxquelles l'espèce humaine est assujettie dans ces passages successifs par les différents états de la civilisation» (Idem, p. 98).

(3) «En d'autres termes, le but essentiel de la politique pratique est, proprement, d'éviter les révolutions violentes qui naissent des entraves mal entendues apportées à la marche de la civilisation, et de les réduire, le plus promptement possible, à un simple mouvement moral, aussi régulier, quoique plus vif, que celui qui agite doucement la société dans le temps ordinaires». (Idem, p. 96). 
na Ordem, ordenar normativamente o Progresso, eis o lema comteano por excelência (1).

Silva Cordeiro desenvolveu esta perspectiva nos Ensaios, ao escrever: «Em todas as fases da civilização há duas ideias que são como os dois polos sobre que roda todo o desenvolvimento social da humanidade: são as ideias de ordem e de progresso. O predomínio exclusivo da primeira dá o estacionamento ou o retrocesso; o da segunda, quando não tem a primeira por base, produz a revolução, que é muitas vezes um desvairamento necessário na vida dos povos. Separadas, estas duas ideias produzem necessariamente os horrores do despotismo ou a anarquia demagógica; juntas, produzem a harmonia do mundo social, d'onde se desentranha plácida e serena a vida humana, como das vertentes opostas se formam os grandes rios, cujas águas vão submergir-se e perder-se nos abismos do Oceano» (2).

Este proselitismo de neófito desaparece completamente das páginas de $A$ crise. Nela se diz que a política positiva, «muito mais conservadora do que liberal», pecara "pelo exagero das promessas em nome da ciência feitas e pelo intelectualismo demasiado abstracto e teórico com que sempre encarou a questão dos pobres com os ricos» (3).

Cordeiro não errou ao censurar o conservadorismo e o intelectualismo da política positiva. É que o positivismo político correspondeu, no seu tempo, às expectativas de grupos burgueses bem definidos, acompanhando-lhes as lutas e as pretensð̃es de afirmação social. Tentemos, portanto, acompanhar paralelamente a teorização política de Comte e os sucessos e vicissitudes da política concreta da França oitocentista.

O período censitário do constitucionalismo monárquico, alarga-se, em França, desde a segunda restauração da monarquia bourbónica à implantação da Segunda República. No decurso dos reinados de Luis XVIII, Carlos X e Luis Filipe de Orleães, a política censitária retirou capacidade eleitoral não apenas aos estratos mais proletarizados

(1) «L'ordre devient alors la condition permanente du progrès, tandis que le progrès constitue le but continu de l'ordre.... le positivisme représente directement le progrès humain comme consistant toujours dans le simple développement de l'ordre fondamental, qui contient nécessairement le germe de tous les progrès possibles». (Сомте, Système de politique positive, in ob. cit., t. $7.0^{\circ}$, p. 105).

(2) Silva Cordeiro, Ensaios...., pp. 220-21.

(3) Idem, A crise..., pp. 388-89. 
da população mas também a vastos sectores da média burguesia, possibilitando assim a constituição duma ampla frente de contestação ao poder estabelecido. O projecto republicano conseguiu portanto unificar sob o mesmo estandarte os adeptos dum democratismo neo-jacobino e os defensores duma resposta política mais radical, de ressaibos babuvistas. No entanto, esta aliança provisória que se estabeleceu entre os anelos dum proletariado incipiente e os objectivos duma pequena e média burguesia e se firmou no seio de sociedades democráticas de feição carbonária, assentou numa plataforma ambígua e precária: a fome biológica das camadas populares não significaria a mesma coisa que a fome política da burguesia, vexada pela exclusão de capacidades políticas. É que a burguesia pretendia apenas o alargamento das capacidades eleitorais, batendo-se por um ideal republicano que pudesse levar a democracia formal ao maior grau possível do seu desenvolvimento. As camadas proletárias, contudo, não se ficavam por aqui, exigindo alterações de fundo no estatuto da propriedade ou, pelo menos, novas definiçōes nos critérios de organização e de remuneração do trabalho. A contradição de fundo, a verdadeira encruzilhada, residia na diversidade de intuitos com que se julgava perseguir um mesmo ideal de revolução: para a pequena e média burguesia o triunfo da revolução consistia em levar o liberalismo ao ponto mais extremo da sua possibilidade de democratização, isto é, ao sufrágio universal; contudo, para as camadas populares, o direito de voto não era encarado como um ponto de chegada. Era antes o ponto de partida que levaria a democracia ao ponto mais extremo da sua possibilidade de socialização. Contudo, sendo imperativo dar corpo a uma estratégia comum de desmembramento do liberalismo censitário, a premência do projecto permitiu a temporária ocultação desta fundamental colisão de finalidades políticas, que só viria a manifestar-se na fase propriamente revolucionária da Segunda República (1).

As primeiras produções de Comte acompanharam de perto este combate político. Secretário de Saint-Simon entre 1817 e 1824, o filósofo secundou a luta do seu mentor espiritual, batendo-se, como ele, pela instauração dum liberalismo avançado, no qual fosse politicamente reconhecida a relevância social das «capacidades» industriais, artificial-

(1) Cfr. Paul Louis, Histoire du socialisme en France, 5. ${ }^{\mathrm{a}}$ ed., Paris, 1950, pp. 93-98; BORRAJo DACRUZ, Sindicalismo obrero en Francia, Madrid, 1956, pp. 63-64; Régine Pernoud, Histoire de la bourgeoisie en France, t. 2. ${ }^{\circ}$, Paris, 1962, pp. 456-74. 
mente afastadas das cadeiras do poder. Foi este o significado da sua colaboração em publicações dirigidas por Saint-Simon, devendo citar-se os artigos que fez incluir no L'Industrie e no L'Organisateur (1). O Cours de Philosophie Positive, dado à estampa entre 1830 e 1842, também acentuava sobremaneira os aspectos dinâmicos do seu projecto sociológico, cobrindo de sarcasmos o constitucionalismo censitário orleanista e invectivando os «metafísicos» e «legistas» que lhe serviam de suporte (2).

A revolução de 1848, produto do envolvimento comum de camadas burguesas e populares, extravasou largamente o acervo das meras reclamaçð̃es sufragistas. A burguesia, que pretendera apenas realizar uma revolução política, cedo reconheceu, estupefacta, que abrira as comportas da contestação social. Atemorizada com a organização das "Oficinas Nacionais», com a institucionalização da "Comissão do Luxemburgo» e com a elaboração duma legislação lesiva para os interesses do seu comércio e da sua indústria, abrirá os braços às soluções conservadoras, engrossando as fileiras do «Partido da Ordem» de Thiers e Falloux. Eliminada a influência socialista de Louis Blanc e Albert no governo, neutralizado o programa neojacobino de Ledru-Rollin, eleito Luís Napoleão Bonaparte presidente da República Francesa, a burguesia, outrora ousada e revolucionária, não pensaria tão depressa em aventuras de destino incerto... Assistiria, impávida, ao conflito que veio a opôr a representação parlamentar ao Príncipe-presidente, manter-se-ia inerte ante o golpe de estado de 2 de Dezembro de 1851 e, no ano seguinte, sufragaria sem titubear «o sobrinho do grande Imperador», no referendo de que saíu o Segundo Império (3).

Voltemos aos trabalhos filosóficos de Augusto Comte. Entre 1851 e 1855 surgem o Système de Politique Positive e o Appel aux Conservateurs, obras que explicitam uma curiosa reorientação política. A primeira pretendeu congraçar no culto da Ordem os adeptos positivistas que o Cours desejara reunir sob o estandarte do Progresso, passando a Estática Social a ocupar o lugar proeminente que anterior-

(1) Cfr. Henri Gounier, La jeunesse d'Auguste Comte... III - Auguste Comte et Saint-Simon, pp. 167-183.

(2) Cfr. Сомте, Cours..., in ob. cit., t. 1. ${ }^{\circ}$, pp. 131-34.

(3) Cfr. Charles Moraze, Les bourgeois conquérants, Paris, 1957, pp. 216-22; Édouard Dolléans, Histoire du mouvement ouvrier - 1830-1871, 7.a ed., t. 1. , Paris, 1967, pp. 229-42; RENÉ RÉmOND, La vie politique en France depuis 1789 (1848-1879), 3. ${ }^{\mathrm{a}}$ ed., t. 2. ${ }^{\circ}$, Paris, s.d., pp. 55-125. 
mente estivera reservado à Dinâmica. Por sua vez, o Appel aux Conservateurs pretendeu servir de base à constituição duma vasta frente intelectual e política contra-revolucionária na qual, sob a chefia estratégica dos positivistas, se pretendia incluir não somente os conservadores mas também os «dignos retrógrados».

Como se vê, em boas razões se estribou Silva Cordeiro quando declarou que a política positiva era «muito mais conservadora do que liberal».

Quanto ao pendor abstracto e intelectualista com que o positivismo abordou a «questão social», deverá referir-se que a lucubração comteana se organizou a partir de considerandos de natureza ética. Entendia-se que a futura regeneração do edifício social se encontrava muito mais dependente do desenvolvimento do sentimento filantrópico do que da repartição e redistribuição das fortunas $\left(^{(}\right)$. De resto, Comte considerava a desigualdade de «luzes» e de riquezas um postulado natural da organização sócio-política (2). O seu sistema assentava na hierarquia funcional decorrente duma suposta «constituição normal da indústria moderna», aí avultando a subordinação dos trabalhadores aos empreendedores e das capacidades manuais às capacidades intelectuais ( $\left.{ }^{3}\right)$. Reconhecia-se, portanto, o primado científico das élites

(1) Sobre as apreciações do positivismo comteano acerca das doutrinas proletárias, designadamente as do socialismo e comunismo, vide CомтE, Système...., in $o b$. cit., t. $7 .^{\circ}$, pp. 128-203. Vide também Pierre Arnaud, La pensée d'Auguste Comte, Paris, 1969, pp. 280-294; IDEM, Politique d'Auguste Comte, Paris, 1965, pp. 151-218; Herbert MARCuSE, Razón y revolución, Madrid, 1971, pp. 331-49; Jean LaCroix, La sociologie d'Auguste Comte, Paris, 1956, pp. 82-100.

(2) O tema da desigualdade encontra-se inúmeras vezes glosado na obra de Augusto Comte. Isolamos do Cours duas afirmações significativas: «.... il est évident que les hommes ne sont ni égaux entre eux, ni même équivalents, et ne sauraient, par suite, posséder, dans l'association, des droits identiques, sauf, bien entendu, le droit fondamental, nécessairement commun à tous, du libre développement normal de l'activité personnelle, une fois convenablement dirigée» (СомтE, Cours...., in $o b$. cit., t. $1^{\circ}$, p. 50 ). "Toute société, même la plus restreinte, suppose, par une évidente nécessité, non seulement des diversités, mais aussi des inégalités quelconques» (Idem, p. 449).

(3) «Il n'y a pas plus d'armée sans officiers que sans soldats; cette notion élémentaire convient tout autant à l'ordre industriel qu'à l'ordre militaire. Quoique l'industrie moderne n'ait pu encore être systématisée, la division spontanée qui s'y est graduellement accomplie entre les entrepreneurs et les travailleurs constitue certainement le germe nécessaire de son organisation finale. Aucune grande opération ne serait possible, si chaque exécutant devait aussi être administrateur, ou si la direc- 
pensantes, às quais competia, com exclusividade, a formulação da doutrina demonstrável que presidiria à instauração «científica» do "regime normal». Por outro lado, não se questionava o poder temporal dos grandes potentados industriais e, mais do que isso, considerava-se desejável que se reforçasse o poder económico de direcção do patriciado capitalista através duma livre concentração de capitais (1). Comte esperava que a classe temporalmente dominante se convertesse sem constrangimento, por simples adesão da razão, às demonstrações científicas dos sábios positivistas e ao exaltante projecto sociocrático do «vivre pour autrui». Deste modo, os agentes mais qualificados do monopolismo financista reconhecer-se-iam como a verdadeira «providência material» do proletariado, moderando, por imperativos ético-científicos, as arremetidas dos arbítrios e egoísmos individuais (2). E, proclamada a sujeição do poder temporal ao poder espiritual, competiria, em último termo, à «inteligência» positivista a arbitragem dos improváveis conflitos eventualmente suscitados entre o capital e o trabalho. Por este lado, pareciam estar afastadas as críticas ao carácter plutocrático da solução positivista. Só que, de acordo com a lógica do sistema, o poder subordinante não dispunha, para dirimir contradiçðes nesta área suscitadas, de quaisquer meios coercitivos, o que equivalia a dizer que a eficácia da regulação da ordem política repousava apenas na rigorosa determinação dos mútuos deveres dos cidadãos e na força da opinião pública, entretanto ganha para a causa positivista pelo carácter axiomático das suas demonstrações (3).

tion était vaguement confiée à une communauté inerte et irresponsable» (Idem, Systeme..., in ob. cit., t. $7 .^{\circ}$, p. 159).

(1) «.... la libre concentration des fortunes sera généralement appréciée comme indispensable à leur pleine efficacité, surtout sociale; car de grands devoirs supposent de grandes forces» (СомтE, Système...., in ob. cit., t. 7. $^{\circ}$, p. 376).

(2) Com efeito, a política positiva assinala às camadas populares a natureza essencialmente moral das suas reclamações, chamando correlativamente a atenção dos poderes para as grandes obrigações éticas inerentes à sua posição. Por isso, «les riches se considéreront moralement comme les dépositaires nécessaires des capitaux publics» (СомтE, Cours...., in ob. cit., t. 6. ${ }^{\circ}$, p. 545 ) ou, dito duma forma mais compaginável com a noção de historicidade que perpassa por todo o discurso positivista, «les riches sont les dépositaires naturels des matériaux élaborés par chaque génération pour faciliter l'existence et préparer les travaux de la suivante». (СомтE, Système...., in ob. cit., t. $7 .^{\circ}$, p. 213).

(3) A reparação dos abusos da força material e a correç̧ão das perturbações da ordem normal repousariam na eficácia de mecanismos puramente suasórios, tais 
O distanciamento de Silva Cordeiro resultava, portanto, dos lineamentos exclusivamente morais da política positiva que, por isso, se mostrava incapaz de perspectivar as questões do pauperismo em função de coordenadas económicas. Esta rejeição é particularmente notória nas páginas que $A$ Crise consagra ao estudo do perfil intelectual e político de Teófilo Braga (1). Para Cordeiro, havia que remontar dos efeitos políticos aos factos económicos, já que nestes se encontrava a «causa profunda» das manifestações concretas (2). Por isso, censurou acrimoniosamente a falta de formação económica do patriarca do positivismo português: "Quando até os reis se dizem socialistas, não brada aos céus esta lacuna de estudos económicos num hierofante de literatura que aspira a exercer um «poder moral» (3)? Num outro passo, também altamente significativo pela sua rudeza, interpelando ainda Teófilo, declarava: «Ele, eles positivistas, falam muito de sociocracia e querem apressar a transição da humanidade para um estado que dizem normal e consideram definitivo, quando certamente, não haverá mais lutas entre o capital e o trabalho; mas que têm eles feito em benefício do proletariado? Que importância dão aos problemas económicos na sua sociologia toda teórica? Teófilo, nenhuma» (4).

Esfumadas as fátuas esperanças do humanitarismo positivista, não foram também as promessas liberais que deslumbraram o nosso autor. O liberalismo, esse liberalismo por que tão denodadamente se batera a geração de Herculano, degenerara numa «disciplina organizada a benefício da classe exploradora» (5), num «conúbio místico do banqueiro com o político» (6), que apregoava liberdades e fraternidades «quando nunca o pobre fora tão cruelmente explorado ou opri-

como a censura pública, a excomunhão social ou a reprovação subjectiva. É que, segundo o entendimento do discurso positivista, «la vraie répression religieuse doit toujours aboutir à persuader ou convaincre, sans jamais contraindre» (СомTE, Système...., in ob. cit., t. 8..$^{\circ}$ p. 418).

(1) Silva Cordeiro, A crise...., pp. 369-98.

(2) «.... nos factos económicos é que se encontra sempre a causa profunda de que os fenómenos políticos são já um efeito» (Idem, p. 65); "As questões políticas estão hoje subordinadas, em todo o mundo civilizado, a problemas económicos» (Idem, p. 235).

(3) Idem, p. 391

(4) Idem, p. 385.

(5) Idem, pp. 389-90.

(6) Idem, p. 96. 
mido, nunca o argentário fora mais imoral e insolente, nunca tão distanciadas as classes ou indiferentes» (1).

A dicotomia positivismo-liberalismo não configurava uma alternativa real e credível. Se o primeiro se esvaziava na defesa enfática duma moral social puramente conceptualista, o segundo, fazendo tábua-rasa de quaisquer escrúpulos éticos, perdia-se na corrupção argentária e caciqueira dum rotativismo moribundo.

Não foram, porém, os braços desencantados dum cepticismo sem remédio que acolheram o autor de $A$ Crise, na fase final da sua desenvolução mental. Ensaiando um discurso de rotura, Cordeiro argumentará ser impossível «acabar com o proletariado sem sair dos moldes da sociedade actual» (2). Mas uma nova esperança se poderia opôr ao livre-cambismo económico e ao parlamentarismo burguês da escola de Herculano: a esperança do socialismo, sobretudo na sua forma mutualista e cooperativista, já experimentada com evidente sucesso em alguns países do continente europeu. Este iniludível empenho, esta arreigada crença, transparecem numa passagem em que Silva Cordeiro, exorcizando a sombra gigantesca do exilado de Vale de Lobos, declara: «Ah! se ele vivesse uma dúzia de anos a mais, se lhe fosse dado assistir ao movimento cooperativo da Bélgica, ou a essa campanha messiânica do marxismo e do lassallismo, se conhecesse o que por lá vai já hoje de «bolsas de trabalho», de «trades-unions», de seguros operários, se atentasse sobretudo na reviravolta que a esse respeito mostram os últimos 10 anos da Inglaterra, - talvez que o grande mestre, ficando a meio caminho da conversão, mandasse bugiar o liberalismo que pouco mais tem sido, em Portugal, que um sistema de exploração, instituindo a favor duma dúzia de políticos conluiados com outra dúzia de banqueiros» (3).

Concluamos, portanto, com a afirmação de que com a entrada de Silva Cordeiro para a cadeira de Filosofia do Curso Superior de Letras, no dealbar do século XX, não são já as preocupações dum republicanismo positivista, «à Teófilo Braga», que para aí se transportam. São antes os horizontes do mutualismo socialista.

\section{Amadeu Carvalho Homem}

(1) Idem, p. 55.

(2) Idem, p. 52.

(3) Idem, pp. 49-50. 